\title{
Geochemistry of surface sediments from the northwestern Gulf of Mexico: implications for provenance and heavy metal contamination
}

\author{
John S. ARMSTRONG-ALTRIN ${ }^{1, *}$, Alfonso V. BOTELLO ${ }^{1}$, Susana F. VILLANUEVA ${ }^{1}$ and Luis A. SOTO ${ }^{1}$
}

1 Universidad Nacional Autónoma de México, Instituto de Ciencias del Mar y Limnología, Unidad de Procesos Oceánicos y Costeros, Circuito Exterior s/n, 04510 CDMX., México

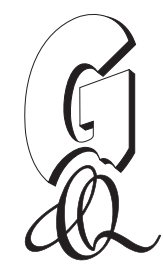

Armstrong-Altrin, J.S., Botello, A.V., Villanueva, S.F., Soto, L.A., 2019. Geochemistry of surface sediments from the northwestern Gulf of Mexico: implications for provenance and heavy metal contamination. Geological Quarterly, 63 (3): 522-538 doi: 10.7306/gq.1484

Associate Editor - Wojciech Granoszewski

Thirty-five near-surface sediment samples were recovered from the continental shelf and upper slope regions of the northwestern (NW) Gulf of Mexico. The geochemical data of the sediments recovered were examined to investigate the weathering intensity, provenance, palaeo-oxygenation condition, and level of heavy metal contamination. The sediments analysed showed a moderate to high intensity of chemical weathering. Major and trace element concentrations indicated a terrigenous origin, closely related to the weathering of rocks rich in aluminosilicates. The results of this study further revealed that major rivers, the Bravo and Soto La Marina, played an important role in delivering sediments to the study area. The concentration of transition trace elements such as $\mathrm{Cr}, \mathrm{Cu}, \mathrm{Ni}$, and $\mathrm{V}$ revealed that the sediments were derived from intermediate rocks such as andesite. The $\mathrm{V} / \mathrm{Cr}, \mathrm{Ni} / \mathrm{Co}$, and $\mathrm{Cu} / \mathrm{Zn}$ ratios in the sediments were $<2,<5$, and $<1$, respectively, suggesting a depositional process occurred under well-oxygenated conditions. Principle Component Analysis (PCA) did not show a significant difference in sediment texture between the continental shelf and slope areas. The enrichment factor (EF) and Geo-accumulation index $\left(I_{g e o}\right)$ values were $<2$ and $<1$, respectively, suggesting the absence of an anthropogenic input.

Key words: Tamaulipas, deep-sea sediments, enrichment factor, contamination, principle component analysis.

\section{INTRODUCTION}

The chemical composition of detrital sediments is commonly used as a sensitive indicator of provenance (Verma and Armstrong-Altrin, 2013, 2016; Basu, 2017; Tzifas et al., 2019), to identify weathering conditions (Gabrielli et al., 2010; Xie and Chi, 2016; Ndjigui et al., 2019), and in several cases as a tool to infer heavy metal contamination (Ramos-Vázquez et al., 2017; Ma et al., 2019; Prabakaran et al., 2019). This is because sediment compositions are mostly influenced by the nature of the sedimentary processes within the depositional basin and kind of dispersal path that links provenance to the basin (Lin et al., 2014; Hou et al., 2017; Pandey and Parcha, 2017; Hernández-Hinojosa et al., 2018; Spalletti et al., 2019).

Trace elements such as $\mathrm{Y}, \mathrm{Cr}, \mathrm{Th}, \mathrm{Zr}, \mathrm{Hf}, \mathrm{Nb}$, and $\mathrm{Ti}$ are best suited for provenance determination, because of their relatively low mobility during sedimentary processes (Cullers, 2000). These elements occur preferentially in resistant miner-

* Corresponding author, e-mail: armstrong@cmarl.unam.mx; john_arms@yahoo.com

Received: August 11, 2018; accepted: May 29, 2019; first published online: September 27, 2019 als and are not released during weathering and transportation, and thus might best reflect the signature of the parent materials (McLennan et al., 1993). Therefore, they are expected to be more useful than major elements in discriminating source rock compositions (Armstrong-Altrin et al., 2004, 2013, 2015a, b; Qiu et al., 2014; Zaid, 2013, 2017; Etemad-Saeed et al., 2015; Verma et al., 2016; Ma et al., 2017; Chaudhuri et al., 2018). Similarly, the distribution of immobile elements, such as La and Th (enriched in silicic rocks) and $\mathrm{Cr}$ and $\mathrm{Co}$ (enriched in basic rocks relative to silicic rocks), have been used to infer the relative contribution of felsic and mafic sources in sediments from different sedimentary environments (Cullers et al., 1988; Madhavaraju and Lee, 2010; Madhavaraju, 2015; Ramachandran et al., 2016; Basu, 2017; Armstrong-Altrin et al., 2017; Madhavaraju et al., 2018; Velmurugan et al., 2019).

The Gulf of Mexico is a region that boasts oil reservoirs of commercial importance, and there are records of several large-scale oil spills in the area (Botello et al., 2015). The "Ixtoc I" well spill was the first to take place in the SW Gulf of Mexico, and it continued for roughly nine months. A volume of $\sim 475,000$ metric tons of crude oil was released into the sea. The northern Gulf of Mexico recently underwent the greatest disaster in oceanic oil spill history, i.e., the collapse of the Deepwater Horizon platform, the property of British Petroleum (BP) in April 2010, 4.9 million barrels of oil were spilled within three months (Zhang et al., 2018). 
Few studies have investigated the provenance of coastal sediments, based on textural and geochemical characteristics, along the northern Gulf of Mexico (Kasper-Zubillaga et al., 2013; Armstrong-Altrin and Natalhy-Pineda., 2014; Armstrong-Altrin et al., 2015b; Hernández-Hinojosa et al., 2018). Kasper-Zubillaga et al. (2013) studied the geochemistry of beach sands from the northern part of the Gulf of Mexico and suggested that they may be used to identify the depositional environment of the sedimentary basin. Armstrong-Altrin and Natalhy-Pineda (2014) inferred the provenance based on surface microtextures on quartz grains from three beach areas in the Gulf of Mexico. Hernández-Hinojosa et al. (2018) addressed the textural and geochemical characteristics of beach sands along the western Gulf of Mexico. Tapia-Fernandez et al. (2017) studied the chemistry and U-Pb geochronology of detrital zircons in the Brujas beach and revealed the importance of rivers in contributing sediments to the Southwestern Gulf of Mexico. Recently, Armstrong-Altrin (2015) and Armstrong-Altrin and Machain-Castillo (2016) discussed the provenance of continental slope sediments from the southwestern Gulf of Mexico. Similarly, the heavy metal concentrations of the estuary sediments from the Gulf of Mexico have been documented by Botello et al. (2015) and Rosales-Hoz et al. (2015). However, provenance studies based on sediment geochemistry in the NW Gulf of Mexico are limited.

This article discusses the geochemistry of surface sediments recovered from the NW part of the Gulf of Mexico. It provides information on weathering intensity, sedimentary provenance, palaeo-oxygenation conditions and quantifies the level of heavy metal contamination in the sediments.

\section{STUDY AREA}

The study area extends along the NW Gulf of Mexico between $25^{\circ} 32^{\prime} 74.33^{\prime \prime} \mathrm{N}-95^{\circ} 44^{\prime} 33.83^{\prime \prime} \mathrm{W}$ and $22^{\circ} 32^{\prime} 81.83^{\prime \prime} \mathrm{N}-97^{\circ}$ $56^{\prime} 94.17^{\prime \prime} \mathrm{W}$, including shelf and upper slope regions from 48 to $2329 \mathrm{~m}$ depth (Fig. 1). This sector of the Gulf of Mexico is strongly influenced by the cyclone and anticyclone gyres derived from the Loop Current. The surface oceanic circulation is predominantly towards the north, while these cyclonic processes are absent in the NW part of the Gulf of Mexico. The salinity and vertical density profiles obtained during the winter season indicated the intrusion of cold and diluted water originated from the Louisiana-Texas continental shelf (Monreal-Gómez and Salas de León, 1990; Salas de Salas-de-Leon et al., 1992). The depositional conditions on the shelf are profoundly influenced by the river runoff of three main rivers, namely the Bravo, Soto La Marina, and Panuco, and by the exporting capacity of two major coastal lagoons, namely the Madre and Tamiahua (Fig. 1). Deep-water sediments of the Gulf of Mexico are essentially biogenic with a predominance of silty clay and are impoverished in organic material (Botello et al., 2015; Kasper-Zubillaga et al., 2019).

\section{CLIMATE AND SIMPLIFIED GEOLOGY}

The Gulf of Mexico climate is considered as sub-humid to humid (Tamayo, 1991; Salas-Monreal et al., 2018). There are three well-defined climatic conditions in the Gulf of Mexico:

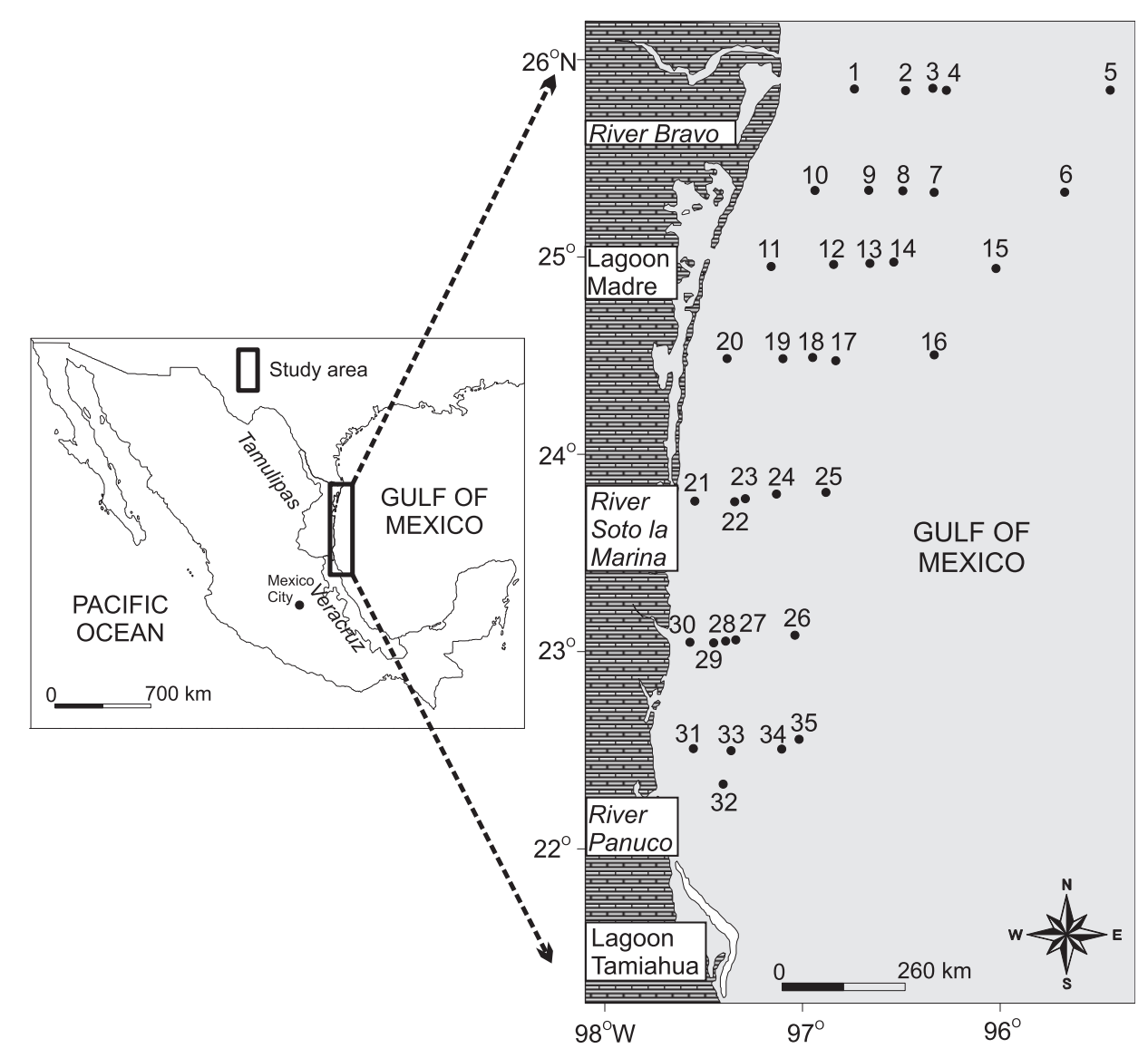

Fig. 1. Simplified map of the study area showing sample locations in the NW Gulf of Mexico (map modified after Botello et al., 2015) 
- dry (February-May);

- rainy (June-November);

- windy (northern winds, 50-70 knots speed; YañezArancibia and Day, 1982).

The outcrops along the Gulf of Mexico are composed of: - Quaternary alluvium and soils;

- Cenozoic and Mesozoic clastic and calcareous sedimentary rocks;

- Cenozoic volcanic rocks of mafic and intermediate type;

- Paleozoic and Precambrian metamorphic rocks comprising schist and gneiss (Ortega-Gutierrez et al., 1995; Verma, 2015).

\section{MATERIALS AND METHODS}

Thirty-five near-surface sediment samples were collected during an oceanographic campaign conducted on board the R/V "Justo Sierra" in July 2010 along the continental shelf and upper slope regions of the NW Gulf of Mexico (Fig. 1). Sediment samples were recovered using a Reineck box-corer at water depths varying from $\sim 48$ to $2329 \mathrm{~m}$ and stored frozen in clean containers until analysis in the laboratory.

\section{GRAIN SIZE ANALYSIS}

Granulometric analysis of sediments was carried out by a Beckman Coulter LS230 Laser diffraction particle size analyser adjusted with a range size of 0.04 and $2000 \mathrm{~mm}$.

\section{SEM-EDS}

Mineral chemistry was measured by a PHILLIPS XL-30 scanning electron microscope (SEM) equipped with energy dispersive spectrometer (EDS) at UNAM, Mexico.

\section{GEOCHEMICAL ANALYSIS}

A total of 35 sediment samples were analysed for major and trace element concentrations. A sequential Siemens SRS 3000 $X$-ray spectrometer, equipped with a $125 \mu \mathrm{m}$ rhodium tube and a beryllium window, was used to measure the major $\left(\mathrm{Al}_{2} \mathrm{O}_{3}\right.$, $\left.\mathrm{Fe}_{2} \mathrm{O}_{3}, \mathrm{MgO}\right)$ and trace $(\mathrm{Cu}, \mathrm{Zn}$, and $\mathrm{Pb}$ ) element concentrations. Errors estimated in the determinations are lower than $1 \%$ for major elements and lower than $4 \%$ for trace elements. In all cases, the calibration curves have been constructed according to international standards. The remaining major elements $\left(\mathrm{SiO}_{2}, \mathrm{TiO}_{2}, \mathrm{MnO}, \mathrm{CaO}, \mathrm{MgO}, \mathrm{Na}_{2} \mathrm{O}\right.$, and $\left.\mathrm{K}_{2} \mathrm{O}\right)$ were analysed by utilizing loss on ignition ( $\mathrm{LOI}$ ) performed on the cast sample (bead). Beads were prepared by mixing $1 \mathrm{~g}$ of powdered sample with $9 \mathrm{~g}$ of $\mathrm{Li}_{2} \mathrm{~B}_{4} \mathrm{O}_{7}-\mathrm{LiBO}$ flux mix (50:50 wt.\%). Before heating, two drops of $\mathrm{LiBr}$ in aqueous solution concentrated at 250 g/L were added.

Analysis of trace elements was performed using a pressed sample, which is prepared by profusely mixing $6 \mathrm{~g}$ of fine powder (particle size $<74$ microns) with $0.6 \mathrm{~g}$ of Hoechst wax $\mathrm{C}$ as a binding agent. The mix is pressed at 30 tons, and the pressure is sustained for 30 seconds. The device being used is a Graseby/Specac press, as well as a pellet casting die, measuring $4 \mathrm{~cm}$ in diameter. The die is equipped with a mechanism that evacuates gas, thus avoiding pellet surface irregularities. For sample series, one duplicate is prepared per 10 samples to verify repetition of preparation conditions.

\section{RESULTS}

\section{MAJOR ELEMENT CONCENTRATIONS}

The major element data are listed in Table 1. The major element concentrations were normalized with average upper continental crust values (UCC; Taylor and McLennan, 1985) and are shown in Figure 2. Relative to UCC the sediment samples are slightly enriched in $\mathrm{TiO}_{2}, \mathrm{Al}_{2} \mathrm{O}_{3}, \mathrm{MnO}$, and $\mathrm{CaO}$ contents. The variation in $\mathrm{MnO}$ content among sediment samples is significant, and is higher than in average UCC. The $\mathrm{K}_{2} \mathrm{O}$ and $\mathrm{Na}_{2} \mathrm{O}$ contents in sediments are slightly depleted relative to UCC.

$\mathrm{Al}_{2} \mathrm{O}_{3}$ content displayed a very uniform distribution, with slightly higher values at stations $3,9,12$ and 17 , with a range from $\sim 16.2$ to 16.9 wt. $\%$ (number of samples $n=35$ ), at shallow depth ( $<500 \mathrm{~m}$ isobaths). Low concentrations of $\mathrm{Al}_{2} \mathrm{O}_{3}$ (the mean with one-standard-deviation value being $13.3 \pm 1.7$ ) were observed in locations in front of the rivers Bravo, Soto La Marina, and Panuco (Fig. 3A). The average $\mathrm{Al}_{2} \mathrm{O}_{3}$ content in deep-sea sediments reported by Chester (2000) is $9.5 \mathrm{wt} . \%$. However, sediments of this study displayed concentrations higher than this value $(\sim 9.5-16.9 \% ; 13.3 \pm 1.7)$, which is probably due to the higher amount of terrigenous materials in the NW Gulf of Mexico. On the other hand, the behaviour of $\mathrm{Fe}_{2} \mathrm{O}_{3}$ ( 3.58-5.81 wt.\%; $5.16 \pm 0.47)$ is quite similar to that of $\mathrm{Al}_{2} \mathrm{O}_{3}$, which likely indicates its terrigenous origin (Fig. 3B). The high $\mathrm{Fe}_{2} \mathrm{O}_{3}$ contents ( $\sim 50$ to 5.81 wt. \%) are observed at $<500 \mathrm{~m}$ isobaths, in stations $3,4,7,14,17,18,19,23$, and 24 . The $\mathrm{Fe}_{2} \mathrm{O}_{3}$ content decreases between 500 and $1500 \mathrm{~m}$ isobaths $(5.02 \%)$ and at the mouth of the River Bravo (3.58 wt.\%).

The MgO content varies between 1.69 and $2.83 \mathrm{wt} \%$ (2.44 $\pm 0.22, n=35$ ). The high $\mathrm{MgO}$ contents are observed in stations 7,13 and 14 , which vary between 500 and $1000 \mathrm{~m}$ isobaths and are low in the surrounding areas (Fig. $3 \mathrm{C}$ ). The lowest $\mathrm{MgO}$ values are observed in stations 1 and 26 at $\sim 1500 \mathrm{~m}$ isobaths (1.69 and $1.87 \mathrm{wt} \%$, respectively), which are located in front of the river mouth (River Bravo). Except station 1, the remaining stations exhibited values above the $\mathrm{Mg}$ baseline for deep water sediments proposed by Chester (2000), which is $1.8 \%$. The high $\mathrm{MgO}$ contents at stations 7,13 , and 14 are probably due to the concentration of organic matter, which tends to trap certain metals to form chelates (Table 1).

The correlation between $\mathrm{SiO}_{2}$ and $\mathrm{Al}_{2} \mathrm{O}_{3}$ is statistically not significant at $99 \%$ confidence level $(r=-0.34, n=35$; critical $t$ value for $99 \%$ confidence level is 0.418 ; Verma, 2005), indicating that $\mathrm{SiO}_{2}$ content is mainly controlled by quartz (Nagarajan et al., 2015, 2017). Similarly, a statistically insignificant correlation between $\mathrm{Al}_{2} \mathrm{O}_{3}$ and $\mathrm{TiO}_{2}$ contents $(r=0.39, n=35)$ suggests that clay minerals are not the main controller of $\mathrm{TiO}_{2}$ concentration in sediments (Zaid and Gahtani, 2015; AnayaGregorio et al., 2018). A significant correlation between $\mathrm{Fe}_{2} \mathrm{O}_{3}$ and $\mathrm{TiO}_{2}$ contents $(r=0.56, n=35)$ probably indicates the concentration of detrital minerals like magnetite and ilmenite 
Major element concentrations [weight \%] for the surficial sediments of the NW Gulf of Mexico

\begin{tabular}{|c|c|c|c|c|c|c|c|c|c|c|c|c|c|}
\hline Sample & $\mathrm{SiO}_{2}$ & $\mathrm{TiO}_{2}$ & $\mathrm{Al}_{2} \mathrm{O}_{3}$ & $\mathrm{Fe}_{2} \mathrm{O}_{3}{ }^{*}$ & $\mathrm{MnO}$ & $\mathrm{MgO}$ & $\mathrm{CaO}$ & $\mathrm{Na}_{2} \mathrm{O}$ & $\mathrm{K}_{2} \mathrm{O}$ & $\mathrm{P}_{2} \mathrm{O}_{5}$ & LOI & Total & $\mathrm{CIA}$ \\
\hline 1 & 69.9 & 0.505 & 9.49 & 3.58 & 0.045 & 1.69 & 2.65 & 2.01 & 2.12 & 0.071 & 7.83 & 99.9 & 75 \\
\hline 2 & 53.0 & 0.612 & 15.0 & 5.27 & 0.079 & 2.58 & 3.59 & 3.61 & 2.53 & 0.136 & 13.4 & 99.8 & 80 \\
\hline 3 & 50.5 & 0.619 & 16.5 & 5.80 & 0.072 & 2.36 & 4.18 & 3.20 & 2.78 & 0.149 & 13.8 & 100.0 & 81 \\
\hline 4 & 50.2 & 0.622 & 15.2 & 5.55 & 0.218 & 2.47 & 4.03 & 4.14 & 2.83 & 0.149 & 14.5 & 99.9 & 76 \\
\hline 5 & 40.5 & 0.491 & 11.0 & 4.76 & 0.323 & 2.38 & 13.8 & 3.09 & 2.28 & 0.131 & 21.0 & 99.8 & 43 \\
\hline 6 & 41.7 & 0.495 & 10.7 & 4.93 & 0.545 & 2.16 & 12.6 & 3.41 & 2.31 & 0.126 & 21.0 & 99.9 & 43 \\
\hline 7 & 49.4 & 0.596 & 13.2 & 5.81 & 0.163 & 2.68 & 5.73 & 4.11 & 2.80 & 0.153 & 15.2 & 99.9 & 65 \\
\hline 8 & 48.6 & 0.595 & 14.5 & 5.28 & 0.058 & 2.42 & 7.39 & 3.17 & 2.66 & 0.128 & 15.1 & 99.9 & 66 \\
\hline 9 & 52.1 & 0.601 & 16.5 & 5.38 & 0.094 & 2.28 & 3.56 & 3.67 & 2.61 & 0.136 & 12.8 & 99.7 & 83 \\
\hline 10 & 56.8 & 0.648 & 13.4 & 5.19 & 0.069 & 2.63 & 3.43 & 3.19 & 2.71 & 0.131 & 11.7 & 99.9 & 77 \\
\hline 11 & 56.2 & 0.655 & 13.0 & 5.17 & 0.063 & 2.64 & 3.81 & 3.35 & 2.72 & 0.117 & 12.3 & 100.0 & 73 \\
\hline 12 & 51.8 & 0.608 & 16.9 & 5.42 & 0.125 & 2.23 & 3.68 & 3.35 & 2.54 & 0.142 & 13.0 & 99.8 & 84 \\
\hline 13 & 48.9 & 0.589 & 12.9 & 5.29 & 0.08 & 2.66 & 7.79 & 3.18 & 2.69 & 0.136 & 15.5 & 99.7 & 60 \\
\hline 14 & 49.6 & 0.602 & 13.2 & 5.57 & 0.087 & 2.67 & 6.46 & 3.49 & 2.80 & 0.139 & 14.8 & 99.4 & 64 \\
\hline 15 & 42.9 & 0.520 & 11.7 & 4.99 & 0.336 & 2.40 & 12.5 & 2.98 & 2.36 & 0.126 & 19.2 & 100.0 & 47 \\
\hline 16 & 41.6 & 0.501 & 13.0 & 4.87 & 0.304 & 2.38 & 12.2 & 3.09 & 2.24 & 0.127 & 19.4 & 99.7 & 51 \\
\hline 17 & 47.7 & 0.564 & 16.2 & 5.79 & 0.156 & 2.22 & 5.65 & 3.80 & 2.48 & 0.154 & 15.1 & 99.9 & 74 \\
\hline 18 & 50.1 & 0.615 & 12.9 & 5.51 & 0.089 & 2.75 & 6.04 & 3.59 & 2.79 & 0.137 & 15.1 & 99.6 & 64 \\
\hline 19 & 52.6 & 0.645 & 13.1 & 5.51 & 0.094 & 2.83 & 4.86 & 3.53 & 2.75 & 0.122 & 14.1 & 100.0 & 69 \\
\hline 20 & 54.7 & 0.636 & 13.4 & 5.25 & 0.063 & 2.28 & 4.94 & 2.92 & 2.63 & 0.137 & 13.0 & 99.9 & 72 \\
\hline 21 & 55.8 & 0.612 & 11.8 & 4.66 & 0.083 & 2.46 & 5.71 & 3.01 & 2.56 & 0.139 & 13.4 & 100.0 & 64 \\
\hline 22 & 52.5 & 0.632 & 12.8 & 5.40 & 0.071 & 2.68 & 5.09 & 3.54 & 2.73 & 0.146 & 14.3 & 99.9 & 67 \\
\hline 23 & 50.2 & 0.619 & 13.8 & 5.51 & 0.171 & 2.67 & 5.10 & 3.65 & 2.62 & 0.139 & 15.2 & 99.7 & 70 \\
\hline 24 & 49.7 & 0.591 & 14.4 & 5.69 & 0.053 & 2.62 & 5.96 & 3.22 & 2.76 & 0.132 & 14.9 & 100.0 & 69 \\
\hline 25 & 45.6 & 0.543 & 12.2 & 5.21 & 0.433 & 2.54 & 10.2 & 3.13 & 2.48 & 0.136 & 17.4 & 99.9 & 53 \\
\hline 26 & 44.3 & 0.536 & 12.3 & 5.11 & 0.229 & 2.13 & 9.97 & 3.03 & 2.40 & 0.129 & 20.6 & 100.7 & 54 \\
\hline 27 & 53.5 & 0.621 & 13.0 & 5.11 & 0.308 & 2.38 & 6.05 & 2.79 & 2.62 & 0.158 & 13.6 & 100.1 & 67 \\
\hline 28 & 50.5 & 0.614 & 14.0 & 5.26 & 0.108 & 2.61 & 5.49 & 3.36 & 2.58 & 0.142 & 15.3 & 100.0 & 70 \\
\hline 29 & 53.9 & 0.646 & 12.4 & 4.95 & 0.075 & 2.58 & 5.82 & 2.98 & 2.68 & 0.128 & 13.5 & 99.6 & 65 \\
\hline 30 & 46.9 & 0.522 & 11.0 & 4.14 & 0.053 & 2.39 & 12.6 & 2.16 & 2.29 & 0.119 & 17.5 & 99.6 & 46 \\
\hline 31 & 55.0 & 0.601 & 11.7 & 4.38 & 0.06 & 2.26 & 6.84 & 2.87 & 2.47 & 0.125 & 13.6 & 99.9 & 61 \\
\hline 32 & 53.2 & 0.589 & 12.5 & 4.73 & 0.063 & 2.36 & 7.05 & 2.81 & 2.62 & 0.125 & 13.5 & 99.6 & 62 \\
\hline 33 & 51.3 & 0.606 & 13.5 & 5.37 & 0.103 & 2.51 & 6.06 & 3.07 & 2.77 & 0.142 & 14.2 & 99.6 & 67 \\
\hline 34 & 48.2 & 0.584 & 15.6 & 5.43 & 0.462 & 2.35 & 6.74 & 3.03 & 2.53 & 0.141 & 15.1 & 100.2 & 71 \\
\hline 35 & 45.1 & 0.524 & 12.3 & 4.88 & 0.279 & 2.36 & \begin{tabular}{|l|}
10.9 \\
\end{tabular} & 2.86 & 2.33 & 0.123 & 18.2 & 99.8 & 52 \\
\hline Mean & $50 \pm 5$ & $0.6 \pm 0.05$ & $13 \pm 1.7$ & $5 \pm 0.5$ & $0.2 \pm 0.1$ & $2.4 \pm 0.2$ & $7 \pm 3$ & $3.2 \pm 0.4$ & $2.6 \pm 0.2$ & $0.13 \pm 0.01$ & $15 \pm 3$ & $100 \pm .2$ & $65 \pm 11$ \\
\hline
\end{tabular}

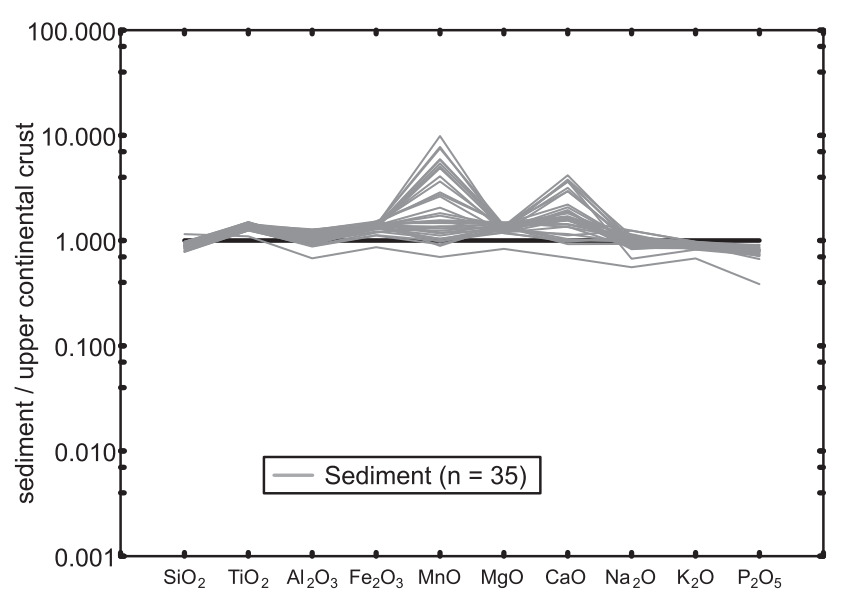

Fig. 2. Multi-element diagram of major element concentrations normalized against average upper continental crust (Taylor and McLennan, 1985)
(Armstrong-Altrin et al., 2012; Hou et al., 2017). This interpretation is further supported by the SEM-EDS analysis, in which magnetite and ilmenite are identified (Fig. 4). Based on the chemical classification diagram the sediments are classified as shale and wacke types (Fig. 5; Herron, 1988).

\section{TRACE ELEMENT CONCENTRATIONS}

The trace element concentrations are reported in Table 2 and the UCC normalized trace element patterns are shown in Figure 6. In comparison with UCC the concentrations of the surface sediment samples are generally low in $\mathrm{Sr}, \mathrm{Zr}, \mathrm{Ba}, \mathrm{Ni}$, and $\mathrm{Nb}$. Exceptionally, sediments from a few stations are enriched in Th and Cu (Fig. 6).

The Cu content varies from 26 to $39 \mu^{-1}$ with a mean value of $32 \pm 3.9 \mathrm{\mu gg}^{-1}$. The highest concentrations, i.e. $46 \mu^{-1}, 39 \mathrm{\mu gg}^{-1}, 38 \mu \mathrm{gg}^{-1}, 36 \mu^{-1} g^{-1}$, and $35 \mu^{-1}$ are recorded at stations $15,16,25,26$ and 35 , respectively, located at $>500 \mathrm{~m}$ isobaths (Fig. 7A). In contrast, the Cu contents are low 

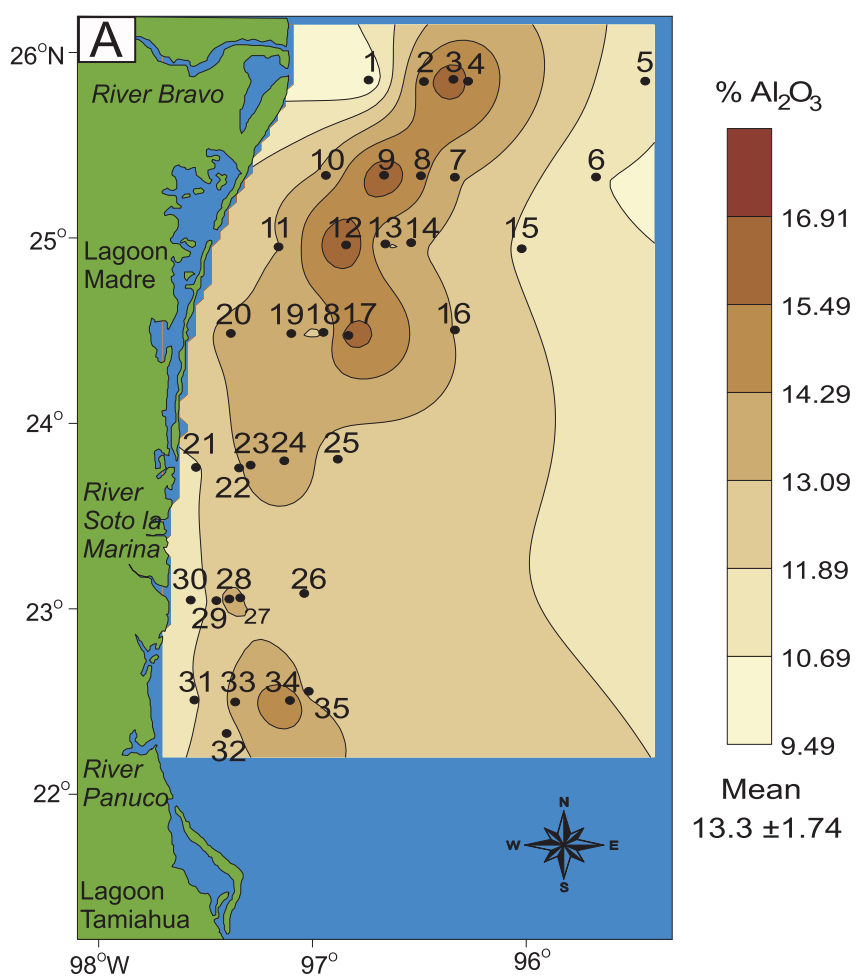

Mean

$13.3 \pm 1.74$
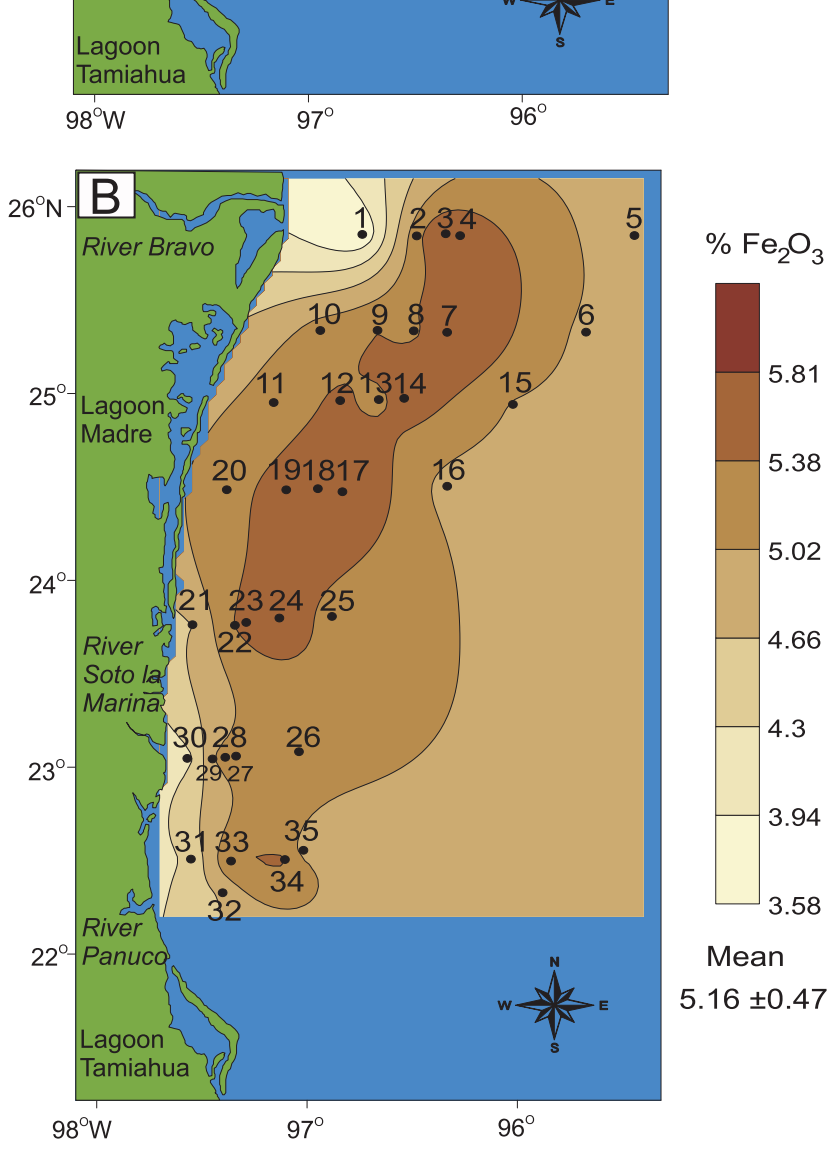

in the stations located closer to the mouth of the Rio Bravo (station 1), Madre Lagoon (station 20), and between the Soto La Marina and Panuco rivers (21, 30 and 31 ; Fig. 1). Similarly, the Cu content decreases as the distance from the coast increases. Cu concentrations at all stations are higher than the sediment quality guideline Effects Range Low (ERL) value for sediments reported by Long et al. (1995), which is $34 \mathrm{\mu gg}^{-1}$; they are, however, lower than the concentration reported by Chester (2000),

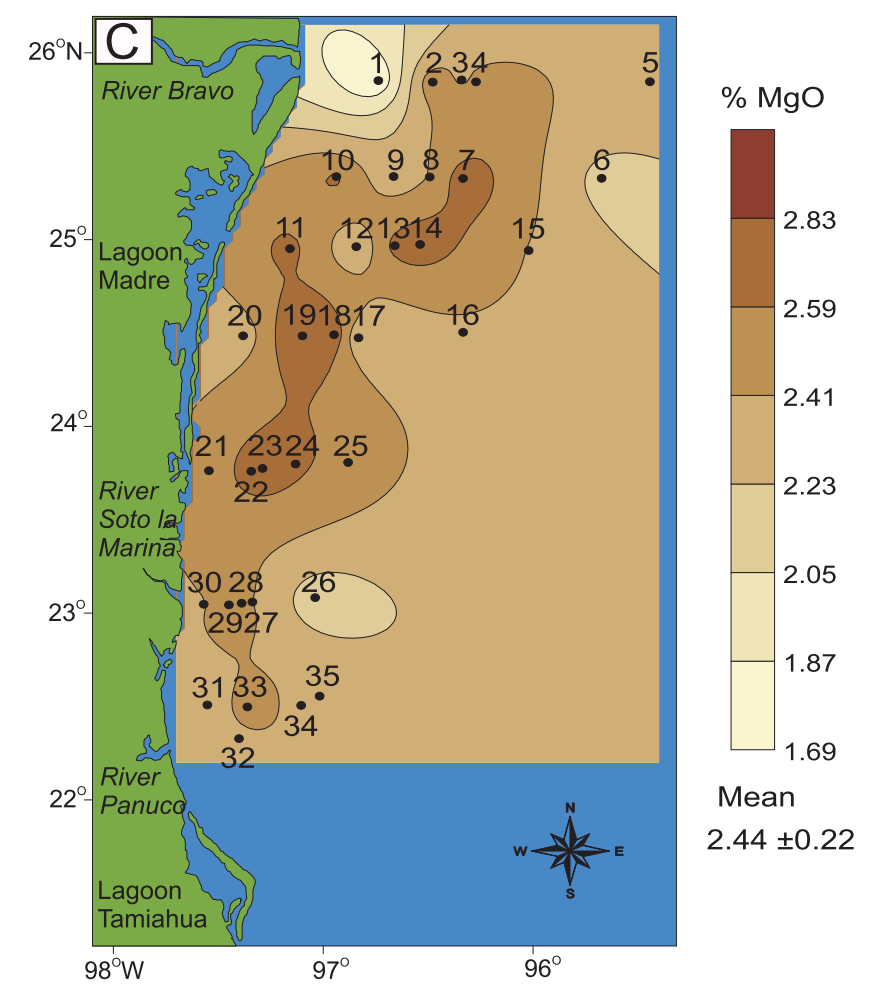

Fig. 3. Spatial distributions of major element concentrations in surficial sediments, NW Gulf of Mexico

$$
\mathrm{A}-\mathrm{Al}_{2} \mathrm{O}_{3}, \mathrm{~B}-\mathrm{Fe}_{2} \mathrm{O}_{3}, \mathrm{C}-\mathrm{MgO}
$$

which is $200 \mu \mathrm{gg}^{-1}$. The low Cu concentration of this study compared with the average values mentioned above indicates that the $\mathrm{Cu}$ is of lithogenic origin.

The $\mathrm{Pb}$ concentration varies from 15 to $25 \mu^{-1}$, with a mean value of $20 \pm 3 \mathrm{\mu gg}^{-1}$. The $\mathrm{Pb}$ content is high $\left(\sim 23-24 \mu^{-1}\right)$, at stations 11, 19, and 23, which are located at $\sim 500 \mathrm{~m}$ isobaths, where the sediment discharge from Madre Lagoon exerts significant detrital influence. Similarly, the $\mathrm{Pb}$ 

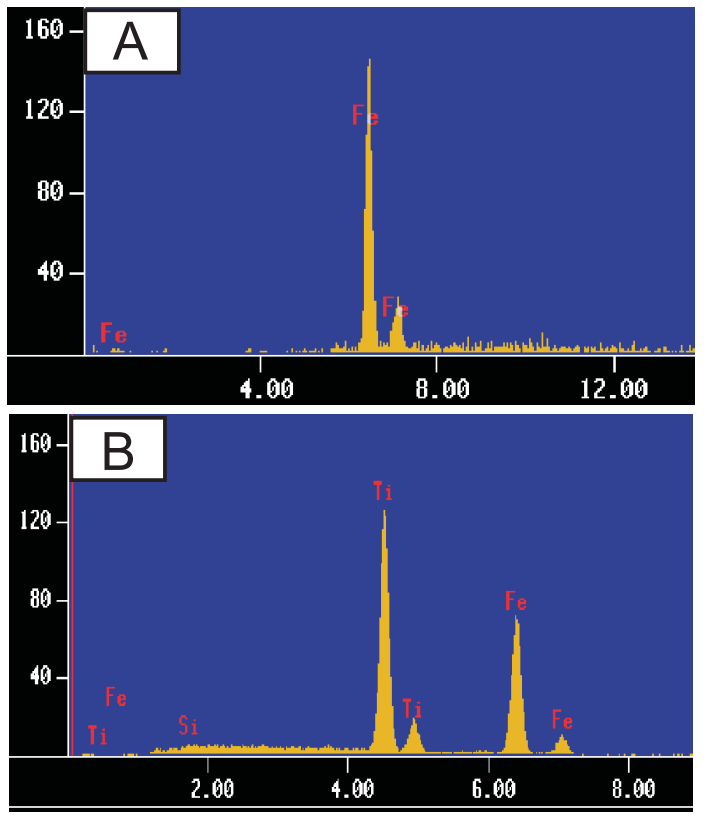

Fig. 4. SEM-EDS spectrum

A - magnetite (sample no. 1), B - ilmenite (sample no. 32)

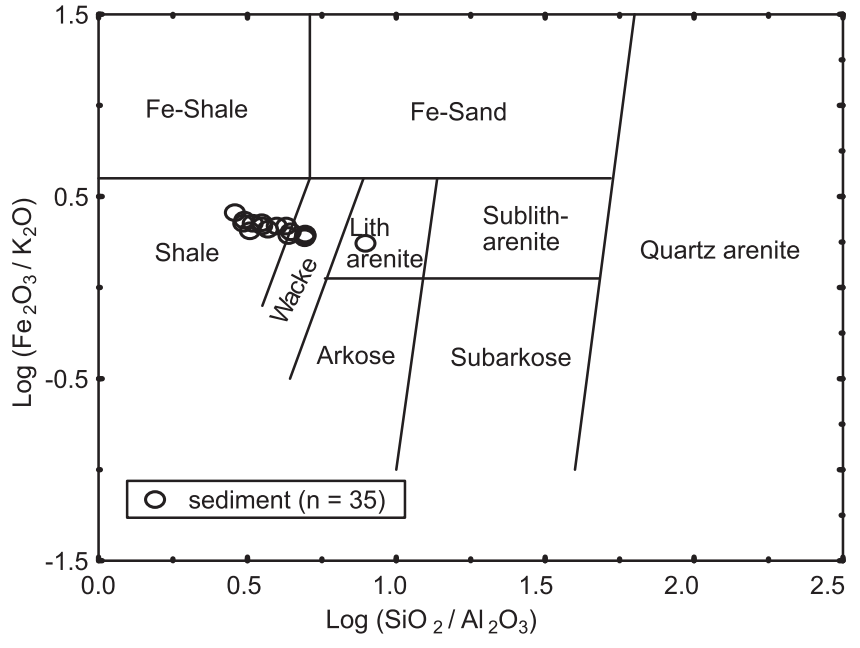

Fig. 5. Geochemical classification diagram using log $\left(\mathrm{Fe}_{2} \mathrm{O}_{3} / \mathrm{K}_{2} \mathrm{O}\right)$ versus $\log \left(\mathrm{SiO}_{2} / \mathrm{Al}_{2} \mathrm{O}_{3}\right)$ (Herron, 1988)

Trace element concentrations [ppm] for the surficial sediments of the NW Gulf of Mexico

\begin{tabular}{|c|c|c|c|c|c|c|c|c|c|c|c|c|c|c|}
\hline Sample & $\mathrm{Ba}$ & Co & $\mathrm{Cu}$ & $\mathrm{Cr}$ & $\mathrm{Nb}$ & $\mathrm{Ni}$ & $\mathrm{Pb}$ & $\mathrm{Rb}$ & $\mathrm{Sr}$ & Th & V & $Y$ & $\mathrm{Zn}$ & $\mathrm{Zr}$ \\
\hline 1 & 395 & 13 & 28 & 116 & 8 & 22 & 17 & 95 & 146 & 10 & 95 & 25 & 75 & 211 \\
\hline 2 & 403 & 11 & 31 & 77 & 12 & 29 & 23 & 122 & 178 & 12 & 135 & 29 & 107 & 167 \\
\hline 3 & 348 & 10 & 30 & 87 & 10 & 30 & 21 & 119 & 177 & 10 & 143 & 27 & 109 & 142 \\
\hline 4 & 357 & 12 & 33 & 75 & 10 & 33 & 24 & 122 & 181 & 11 & 139 & 29 & 114 & 139 \\
\hline 5 & 342 & 15 & 39 & 54 & 9 & 39 & 16 & 95 & 449 & 8 & 115 & 24 & 93 & 127 \\
\hline 6 & 360 & 17 & 46 & 62 & 9 & 43 & 15 & 96 & 427 & 9 & 127 & 25 & 98 & 124 \\
\hline 7 & 347 & 13 & 33 & 71 & 9 & 35 & 21 & 118 & 222 & 10 & 144 & 27 & 112 & 127 \\
\hline 8 & 326 & 14 & 30 & 70 & 11 & 31 & 21 & 116 & 280 & 9 & 134 & 28 & 107 & 147 \\
\hline 9 & 390 & 11 & 30 & 100 & 11 & 29 & 20 & 116 & 149 & 10 & 134 & 28 & 106 & 148 \\
\hline 10 & 464 & 13 & 31 & 73 & 12 & 29 & 22 & 123 & 148 & 10 & 129 & 31 & 109 & 178 \\
\hline 11 & 415 & 11 & 31 & 89 & 14 & 29 & 24 & 121 & 156 & 10 & 129 & 31 & 105 & 180 \\
\hline 12 & 372 & 12 & 31 & 80 & 8 & 30 & 23 & 115 & 133 & 9 & 133 & 27 & 109 & 136 \\
\hline 13 & 305 & 11 & 30 & 94 & 11 & 31 & 18 & 112 & 261 & 9 & 132 & 26 & 100 & 142 \\
\hline 14 & 350 & 13 & 32 & 70 & 11 & 37 & 17 & 122 & 251 & 11 & 145 & 29 & 112 & 140 \\
\hline 15 & 375 & 16 & 39 & 56 & 9 & 41 & 16 & 100 & 406 & 9 & 120 & 26 & 99 & 129 \\
\hline 16 & 334 & 15 & 38 & 55 & 9 & 39 & 15 & 99 & 405 & 9 & 114 & 25 & 97 & 129 \\
\hline 17 & 320 & 13 & 30 & 78 & 11 & 32 & 19 & 113 & 212 & 10 & 125 & 27 & 103 & 134 \\
\hline 18 & 305 & 13 & 31 & 81 & 6 & 31 & 19 & 107 & 146 & 10 & 123 & 25 & 106 & 118 \\
\hline 19 & 334 & 11 & 29 & 69 & 10 & 30 & 25 & 119 & 168 & 10 & 133 & 28 & 108 & 144 \\
\hline 20 & 404 & 10 & 29 & 67 & 12 & 26 & 22 & 115 & 157 & 12 & 129 & 29 & 101 & 163 \\
\hline 21 & 393 & 12 & 28 & 61 & 12 & 25 & 19 & 109 & 183 & 12 & 97 & 29 & 93 & 191 \\
\hline 22 & 356 & 14 & 29 & 102 & 10 & 29 & 23 & 117 & 147 & 10 & 115 & 30 & 106 & 143 \\
\hline 23 & 336 & 13 & 32 & 66 & 12 & 31 & 25 & 121 & 183 & 12 & 134 & 30 & 109 & 143 \\
\hline 24 & 331 & 10 & 32 & 73 & 12 & 31 & 19 & 118 & 210 & 11 & 127 & 27 & 106 & 136 \\
\hline 25 & 372 & 13 & 36 & 81 & 9 & 36 & 15 & 104 & 330 & 9 & 121 & 25 & 98 & 128 \\
\hline 26 & 366 & 13 & 36 & 58 & 10 & 35 & 15 & 105 & 338 & 10 & 113 & 27 & 98 & 133 \\
\hline 27 & 338 & 12 & 30 & 72 & 8 & 28 & 20 & 105 & 152 & 10 & 111 & 27 & 96 & 168 \\
\hline 28 & 357 & 12 & 30 & 98 & 9 & 28 & 21 & 111 & 145 & 10 & 110 & 27 & 101 & 139 \\
\hline 29 & 355 & 11 & 30 & 117 & 11 & 28 & 20 & 111 & 156 & 11 & 120 & 29 & 97 & 162 \\
\hline 30 & 296 & 12 & 26 & 54 & 9 & 23 & 16 & 89 & 492 & 7 & 95 & 25 & 81 & 187 \\
\hline 31 & 338 & 12 & 29 & 60 & 11 & 26 & 18 & 104 & 185 & 10 & 92 & 28 & 88 & 189 \\
\hline 32 & 308 & 12 & 30 & 71 & 11 & 25 & 22 & 108 & 198 & 10 & 102 & 28 & 96 & 168 \\
\hline 33 & 316 & 13 & 31 & 69 & 5 & 28 & 21 & 100 & 122 & 8 & 121 & 24 & 100 & 117 \\
\hline 34 & 330 & 12 & 32 & 65 & 10 & 32 & 23 & 112 & 217 & 11 & 120 & 28 & 106 & 141 \\
\hline 35 & 336 & 13 & 35 & 59 & 9 & 34 & 20 & 99 & 344 & 7 & 105 & 24 & 95 & 131 \\
\hline Mean & $353 \pm 36$ & $12 \pm 2$ & $31 \pm 3$ & $75 \pm 17$ & $10 \pm 2$ & $31 \pm 5$ & $20 \pm 3$ & $110 \pm 9$ & $230 \pm 103$ & $10 \pm 1$ & $121 \pm 14$ & $27 \pm 2$ & $101 \pm 8$ & $148 \pm 23$ \\
\hline
\end{tabular}




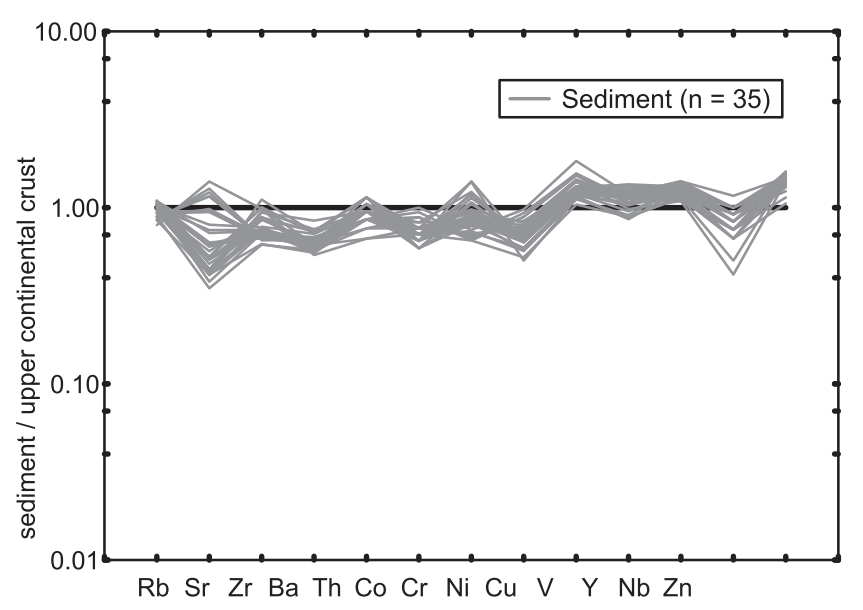

Fig. 6. Multi-element diagram of trace element concentrations normalized against average upper continental crust (Taylor and McLennan, 1985)

concentration decreases in stations farther away from the coast (Fig. 7B). The Pb concentrations at all 35 stations are below the ERL value reported for marine sediments $\left(46.7 \mathrm{\mu gg}^{-1}\right.$; Long et al., 1995), as well as the average value $\left(200 \mu^{-1}\right)$ reported by Chester (2000). The distribution of $\mathrm{Zn}$ in sediments varies from 75 to $114 \mu g^{-1}$ with a mean value of $101 \pm 8{\mu g^{-1}}^{-1}$. The stations that recorded the highest $\mathrm{Zn}$ contents are located at $\sim 500 \mathrm{~m}$ isobaths. Also, except stations 1, 30, 31 and 32, located near to the coast, other stations recorded $\mathrm{Zn}$ concentrations between 100 and $114 \mu^{-1}$ (Fig. $7 \mathrm{C}$ ). The $\mathrm{Zn}$ contents of this study are below the ERL value of marine sediments reported by Long et al. (1995) and Chester (2000), which is $150 \mu^{-1}$. Hence, the low $\mathrm{Zn}$ content of this study may suggest that the origin of $\mathrm{Zn}$ is terrigenous. The average values of transition trace elements $\mathrm{Cr}$ $(75 \pm 16)$ and $\mathrm{Ni}(31 \pm 5)$ are also near to the ERL values of marine sediments (81 and $20.9 \mu^{-1}$, respectively) reported by Long et al. (1995), indicating terrigenous origin (RamosVázquez et al., 2018; Taheri et al., 2018). A wide variation in $\mathrm{Zr}$ $\left(\sim 117-211{\mu g g^{-1}}^{-1}\right.$ and $\mathrm{Sr}\left(\sim 122-449 \mu^{-1} g^{-1}\right)$ contents in sediments among stations probably indicates the fractionation of minerals during transportation and deposition (Tapia-Fernandez et al., 2017).

\section{DISCUSSION}

\section{WEATHERING CONDITION IN THE SOURCE AREA}

The degree of alteration of feldspars to clays indicates both the degree of weathering of source rocks and that of the diagenesis experienced by the sediments since deposition (Nesbitt et al., 1997; Liu et al., 2016; Yang and Du, 2017). Various weathering indices have been developed and are extensively used by researchers to identify the chemical weathering intensity of the source area (e.g., Price and Velbel, 2003; Lee, 2009; Armstrong-Altrin et al., 2014). Some examples are weathering index of Parker (WIP; Parker, 1970), chemical index of weathering (CIW; Harnois, 1988), chemical index of alteration (CIA; Nesbitt and Young 1982) and Plagioclase index of alteration (PIA; Fedo et al., 1995). Among these weathering indices, a chemical index widely used to determine the degree of source area weathering is the chemical index of alteration
(CIA; Paikaray et al., 2008; Madhavaraju et al., 2016, 2017; Yang and Du, 2017; Kelepile et al., 2017; Wang et al., 2017, 2018; Armstrong-Altrin et al., 2018). This can be calculated using the formula (molecular proportions):

$$
\mathrm{ClA}=\left[\mathrm{Al}_{2} \mathrm{O}_{3} /\left(\mathrm{Al}_{2} \mathrm{O}_{3}+\mathrm{CaO}^{*}+\mathrm{Na}_{2} \mathrm{O}+\mathrm{K}_{2} \mathrm{O}\right)\right] \times 100
$$

where: $\mathrm{CaO}^{*}$ is the amount of $\mathrm{CaO}$ incorporated in the silicate fraction of the rock.

In general, the Ca content in sediments is sourced from inorganic carbon and $\mathrm{Na}$ may be associated with sea-salt. The Ca content in the silicate fraction was calculated by the equation (Martinez et al., 2010):

$$
\mathrm{Ca}=\mathrm{CaO}_{\mathrm{t}}-\mathrm{CaO}_{\text {trg }} \text { and } \mathrm{CaO}_{\text {trg }}=\mathrm{Al}_{2} \mathrm{O}_{3 \mathrm{t}} \times\left(\mathrm{CaO} / \mathrm{Al}_{2} \mathrm{O}_{3}\right)_{\mathrm{ucc}}
$$

where: " $\mathrm{t}$ " = the total abundance in the sample and "trg" = terrigenous.

Similarly, excess $\mathrm{Na}\left(\mathrm{Na}_{\text {excess }}\right)$ in sediments was calculated by the equation:

$$
\mathrm{Na}_{\text {excess }}=\left(\mathrm{Na}_{2} \mathrm{O} \times 0.7419\right)-\left(0.1 \times \mathrm{Al}_{2} \mathrm{O}_{3} \times 0.5292\right)
$$

where: $\mathrm{Na}_{\text {excess }}$ is the pore water salt component of $\mathrm{Na}$ (Murray and Leinen 1996; Armstrong-Altrin and Machain-Castillo, 2016).

According to Nesbitt and Young (1982), CIA values of unaltered plagioclase and K-feldspar are approximately equal to 50 and higher $\mathrm{CIA}$ values (>70) are indicative of intense chemical weathering. The CIA values for the sediment samples range from $\sim 43$ to 84 , which indicate a moderate to high intensity of chemical weathering in the source area (Table 1). This result is also in agreement with the slightly elevated $\mathrm{Rb} / \mathrm{Sr}$ ratios $(>1)$ of the surface sediments ( 0.84-1.13), because intensive chemical weathering may lead to increase the $\mathrm{Rb} / \mathrm{Sr}$ ratio, and high ratios (>1) are indicators of intense weathering (McLennan et al., 1993)

\section{SEDIMENT PROVENANCE}

The discriminant function diagram proposed by Roser and Korsch (1988) is frequently used by many researchers to infer sediment provenance (Tawfik et al., 2017, 2018). This diagram helps to discriminate four provenance categories, i.e., mafic $(\mathrm{P} 1)$, intermediate (P2), felsic (P3) and quartzose recycled (P4). On this diagram, sediment samples plot in the intermediate igneous provenance field (Fig. 8). It seems that the surface sediments of the NW Gulf of Mexico were derived mostly from the contribution of intermediate igneous rocks (e.g., andesite). Similarly, based on the $\left(\mathrm{SiO}_{2}\right)_{\text {adj }}$ content the sediments are classified mainly as of intermediate type (Fig. 9; Le Bas et al., 1986; Armstrong-Altrin, 2009), which is consistent with our interpretation based on the Roser and Korsch (1988) provenance classification.

High concentrations of $\mathrm{Cr}$ (>150 ppm) and $\mathrm{Ni}(>100 \mathrm{ppm}$ ) in sediments are suggestive of ultramafic rocks in the source area (Garver et al., 1996; Armstrong-Altrin et al., 2004). The Cr and $\mathrm{Ni}$ contents in the sediments vary between $\sim 54-117 \mathrm{ppm}$ and $\sim 22-43 \mathrm{ppm}$, respectively, indicating that the sediments were likely derived from intermediate rocks (Table 2). In addition, in the ternary diagram of $\mathrm{Ni}-\mathrm{Th}^{*} 10-\mathrm{V}$ the sediments plot near to the average composition of andesite, which also suggests that the sediments were derived by the weathering of intermediate 

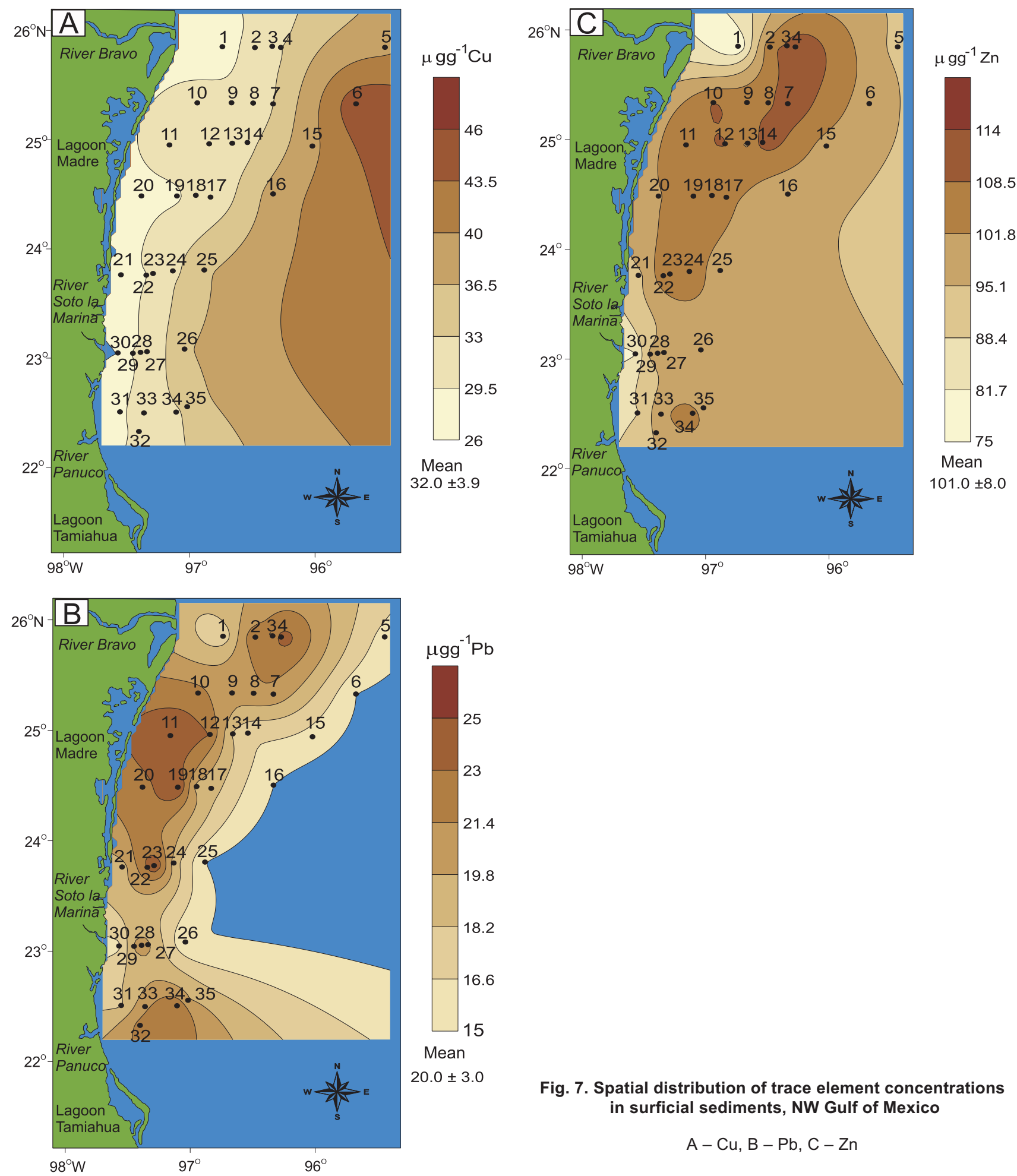

Fig. 7. Spatial distribution of trace element concentrations in surficial sediments, NW Gulf of Mexico

$$
\mathrm{A}-\mathrm{Cu}, \mathrm{B}-\mathrm{Pb}, \mathrm{C}-\mathrm{Zn}
$$

rocks (Bracciali et al., 2007; Fig. 10). Average geochemistry data of the probable source rocks plotted in Figure 10 are compiled from Verma (1999, 2000, 2001a, b), Carrasco-Núñez et al. (2005), and Schaaf et al. (2005), which are located along the coastal areas of the Gulf of Mexico.

\section{PALAEO-OXYGENATION CONDITION}

In many studies, the $\mathrm{V} / \mathrm{Cr}$ ratio has been used as an index to identify the paleo-oxygenation condition (Dill et al., 1988; Jones

and Manning, 1994; Morford and Emerson, 1999; Hu et al., 2017; Bansal et al., 2018). Cr is mainly incorporated in the detrital fraction of sediments, and it may substitute for Al in the clay structure (Riquier et al., 2006). Vanadium may be bound to organic matter by the incorporation of $\mathrm{V}^{4+}$ into porphyrins, and is found in sediments deposited under reducing environments (Shaw et al., 1990). If the values are $>2$, it indicates anoxic conditions, whereas values $<2$ suggest more oxidizing conditions (Jones and Manning, 1994). In the present study, the average $\mathrm{V} / \mathrm{Cr}$ ratio in the sediments $(\sim 0.82-2.14 ; 1.68 \pm 0.33)$ is generally $<2$, which indicates that these sediments were deposited 


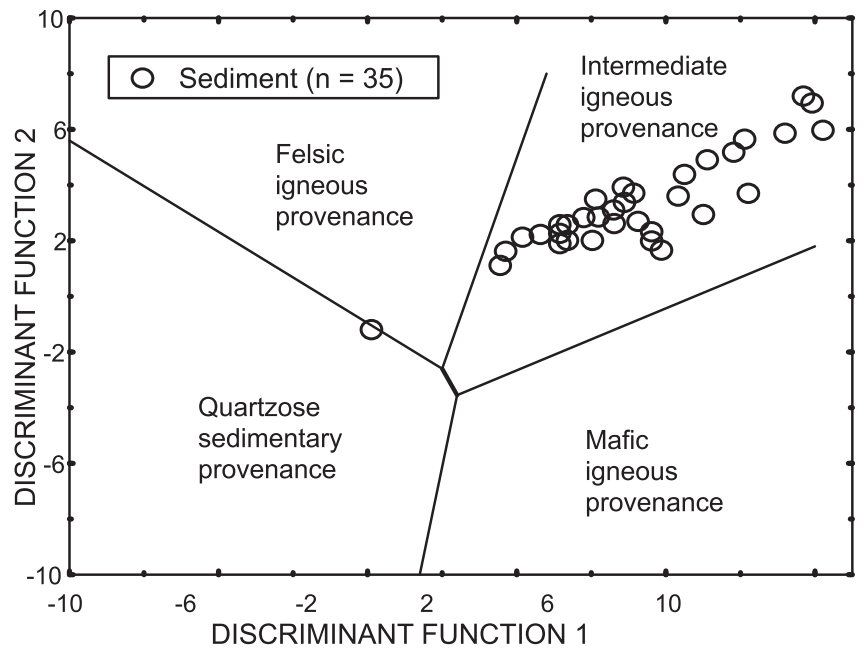

Fig. 8. Major element provenance discriminant function diagram for the sediments (Roser and Korsch, 1988)

The discriminant functions are: discriminant function $1=(-1.773$ $\left.\mathrm{TiO}_{2}\right)+\left(0.607 \cdot \mathrm{Al}_{2} \mathrm{O}_{3}\right)+\left(0.760 \cdot \mathrm{Fe}_{2} \mathrm{O}_{3}\right)+(-1.500 \cdot \mathrm{MgO})+(0.616 \cdot$ $\mathrm{CaO})+\left(0.509 \cdot \mathrm{Na}_{2} \mathrm{O}\right)+\left(-1.224 \cdot \mathrm{K}_{2} \mathrm{O}\right)+(-9.090)$; discriminant function $2=\left(0.445 \cdot \mathrm{TiO}_{2}\right)+\left(0.070 \cdot \mathrm{Al}_{2} \mathrm{O}_{3}\right)+\left(-0.250 \cdot \mathrm{Fe}_{2} \mathrm{O}_{3}\right)+(-1.142$. $\mathrm{MgO})+(0.438 \cdot \mathrm{CaO})+\left(1.475 \cdot \mathrm{Na}_{2} \mathrm{O}\right)+\left(1.426 \cdot \mathrm{K}_{2} \mathrm{O}\right)+(-6.861)$

mostly in an oxic environment. However, slight differences in the $\mathrm{V} / \mathrm{Cr}$ ratio among various stations may suggest a change in the depositional conditions or possibly variations in the oxygen level of the depositional environment.

Numerous studies have applied Ni/Co ratio as a redox indicator (Dypvik, 1984; Dill, 1986; Hua et al., 2013; Arora et al., 2015; Armstrong-Altrin and Machain-Castillo, 2016). Jones and Manning (1994) suggested that a Ni/Co ratio $<5$ indicates an oxic environment, whereas $>5$ suggests sub-oxic and anoxic environments. The $\mathrm{Ni} / \mathrm{Co}$ ratios in these sediments are very low ( 1.69-3.10; $2.50 \pm 0.30)$, which suggest that they were deposited in an oxygenated environment. According to Hallberg (1976), the high Cu/Zn ratio (>1) indicates a redox depositional condition, while low $\mathrm{Cu} / \mathrm{Zn}$ ratio $(<1)$ suggests an oxic condition. The low $\mathrm{Cu} / \mathrm{Zn}$ ratios $(\sim 0.26-0.46 ; 0.32 \pm 0.05)$ in the sediment samples indicate that the sediments were deposited in a welloxidized condition.

\section{STATISTICAL ANALYSIS}

\section{PEARSON CORRELATION}

To evaluate the association among various elements in the surficial sediments, a Pearson correlation analysis was performed. A statistically significant correlation of $\mathrm{Al}_{2} \mathrm{O}_{3}, \mathrm{Fe}_{2} \mathrm{O}_{3}$ and $\mathrm{MgO}$ was observed with $\mathrm{Pb}, \mathrm{Zn}$ and $\mathrm{OM}$ concentrations ( $r=0.54$, 0.72 , and $0.43, r=0.44,0.92$, and 0.39 , and $r=0.40,0.57$ and 0.51 , respectively, $n=35$ ); this implies continental derivation of trace elements combined with terrigenous materials. A significant correlation obtained between $\mathrm{MnO}$ and $\mathrm{CaO}(r=0.61)$ indicates its derivation from a similar source, most probably biogenic. On the other hand, $\mathrm{Fe}_{2} \mathrm{O}_{3}$ and $\mathrm{Zn}$ showed an insignificant correlation with sand percentage $(r=-0.51$ and -0.36 , respectively; $n=35$ ), which indicates that these elements have no affinity with coarse-grained materials. OM did not show signifi-

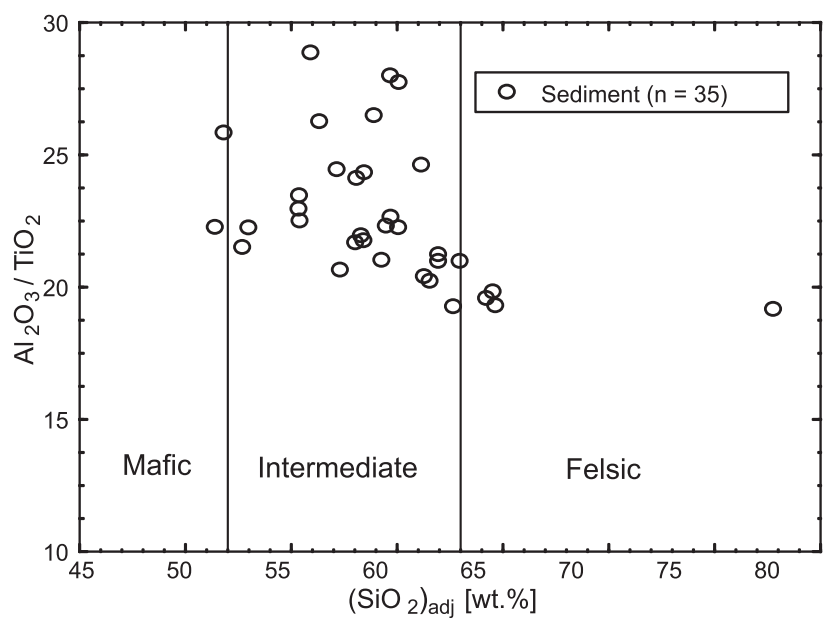

Fig. 9. The $\mathrm{Al}_{2} \mathrm{O}_{3} / \mathrm{TiO}_{2}$ versus $\left(\mathrm{SiO}_{2}\right)_{\text {adj }}$ plot of the surficial sediments, modified after Armstrong-Altrin (2009)

$$
n=\text { number of samples }
$$

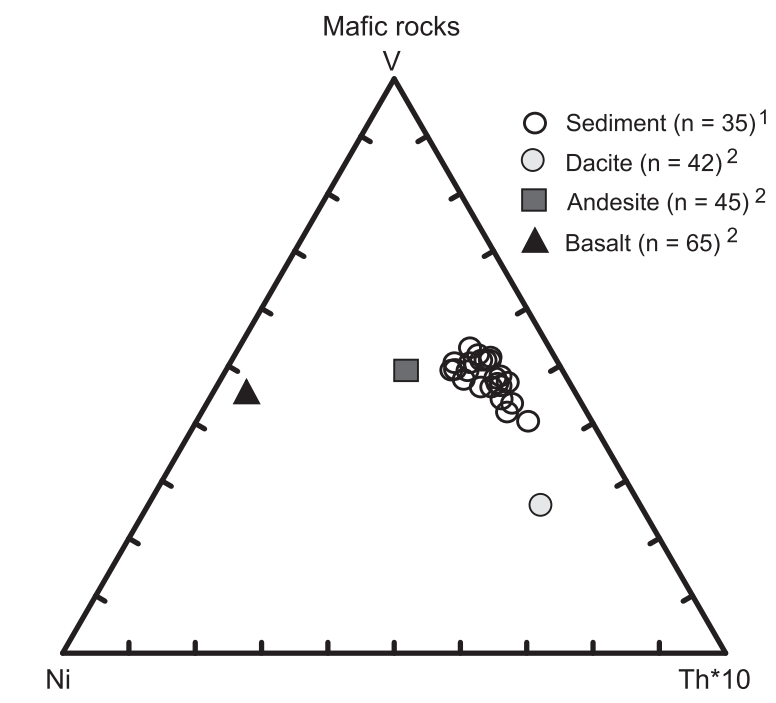

Ultramafic rocks

Felsic rocks

Fig. 10. Ni-Th*10-V ternary diagram of the surficial sediments from the NW Gulf of Mexico (after Bracciali et al., 2007)

1 - this study, 2 - average data for comparison are from Verma (2001a, b), Verma (2015) and Ortega-Gutierrez et al. (1995)

cant correlation with sand, silt, and clay $(r=-0.14,0.15$, and -0.13 , respectively), whereas it is significant against $\mathrm{Al}_{2} \mathrm{O}_{3}(r=$ $0.43, n=35), \mathrm{Fe}_{2} \mathrm{O}_{3}(r=0.39), \mathrm{MgO}(r=0.41), \mathrm{Pb}(r=0.51)$, and $\mathrm{Zn}(r=0.37, n=35)$, which suggests that in some cases it may form chelates. A statistically insignificant correlation between sand and clay $(r=-0.72, n=35)$ may correspond to grain size variations (Table 3$)$.

\section{CLUSTER ANALYSIS}

Cluster analysis is an exploratory data technique employed to classify groups and subgroups based on the similarities and dissimilarities among variables (Hair et al., 2001; Verma, 2005). 
Displayed groups are set by variables (Fig. 11). Practically, one single group is observed in which a greater similarity among concentrations of $\mathrm{Al}_{2} \mathrm{O}_{3}, \mathrm{~Pb}, \mathrm{CaO}, \mathrm{Fe}_{2} \mathrm{O}_{3}, \mathrm{MgO}, \mathrm{OM}, \mathrm{MnO}$, and sand is identified, due to their terrigenous origin and to the high affinity of these elements with OM particles to form chelates. These variables exhibited very similar spatial distribution, with accumulation towards shallow waters (Figs. $3 A-C$ and $7 A-C$ ). The subgroup of silt and $\mathrm{Zn}$ was amalgamated to this group, suggesting that some of the elements mentioned are transported in fine-grained (silt) particles present in the sediments. Another subgroup was amalgamated to the one mentioned previously, in which concentrations of $\mathrm{Cu}$ are linked to percentages of clay; this group was dominated by fine particles, to which $\mathrm{Cu}$ showed a high affinity. As a result, it was highly dissimilar to the main group of terrigenous materials (Fig. 11).

Table 3

Pearson correlation matrix for major elements, trace metals, organic matter (OM in \%), and textural parameters (sand, silt, and clay in \%) in the surficial sediments, NW Gulf of Mexico $(n=35 ; p \leq 0.050)$

\begin{tabular}{|c|c|c|c|c|c|c|c|c|c|c|c|c|}
\hline & $\mathrm{Al}_{2} \mathrm{O}_{3}$ & $\mathrm{CaO}$ & $\mathrm{Fe}_{2} \mathrm{O}_{3}$ & $\mathrm{MgO}$ & $\mathrm{MnO}$ & $\mathrm{Pb}$ & $\mathrm{Cu}$ & $\mathrm{Zn}$ & Sand & Silt & Clay & $\mathrm{OM}$ \\
\hline $\mathrm{Al}_{2} \mathrm{O}_{3}$ & 1.00 & & & & & & & & & & & \\
\hline $\mathrm{CaO}$ & 0.51 & 1.00 & & & & & & & & & & \\
\hline $\mathrm{Fe}_{2} \mathrm{O}_{3}$ & 0.74 & -0.32 & 1.00 & & & & & & & & & \\
\hline $\mathrm{MgO}$ & 0.17 & -0.13 & 0.57 & 1.00 & & & & & & & & \\
\hline $\mathrm{MnO}$ & -0.15 & 0.61 & 0.01 & -0.20 & 1.00 & & & & & & & \\
\hline $\mathrm{Pb}$ & 0.54 & -0.72 & 0.44 & 0.40 & -0.37 & 1.00 & & & & & & \\
\hline $\mathrm{Cu}$ & -0.24 & 0.66 & 0.04 & -0.13 & 0.80 & -0.48 & 1.00 & & & & & \\
\hline $\mathrm{Zn}$ & 0.72 & -0.40 & 0.92 & 0.60 & -0.04 & 0.57 & 0.06 & 1.00 & & & & \\
\hline Sand & -0.27 & -0.05 & -0.51 & -0.32 & -0.09 & -0.04 & -0.09 & -0.36 & 1.00 & & & \\
\hline Silt & 0.17 & -0.43 & -0.10 & -0.16 & -0.18 & 0.37 & -0.26 & 0.09 & 0.66 & 1.00 & & \\
\hline $\mathrm{Clay}$ & -0.13 & 0.40 & 0.14 & 0.18 & 0.18 & -0.34 & 0.25 & -0.04 & -0.72 & -1.00 & 1.00 & \\
\hline$\% \mathrm{OM}$ & 0.43 & -0.52 & 0.39 & 0.41 & -0.54 & 0.51 & -0.63 & 0.37 & -0.14 & 0.15 & -0.13 & 1.00 \\
\hline
\end{tabular}

Tree Diagram for 12 Variables

Single Linkage

Euclidean distances

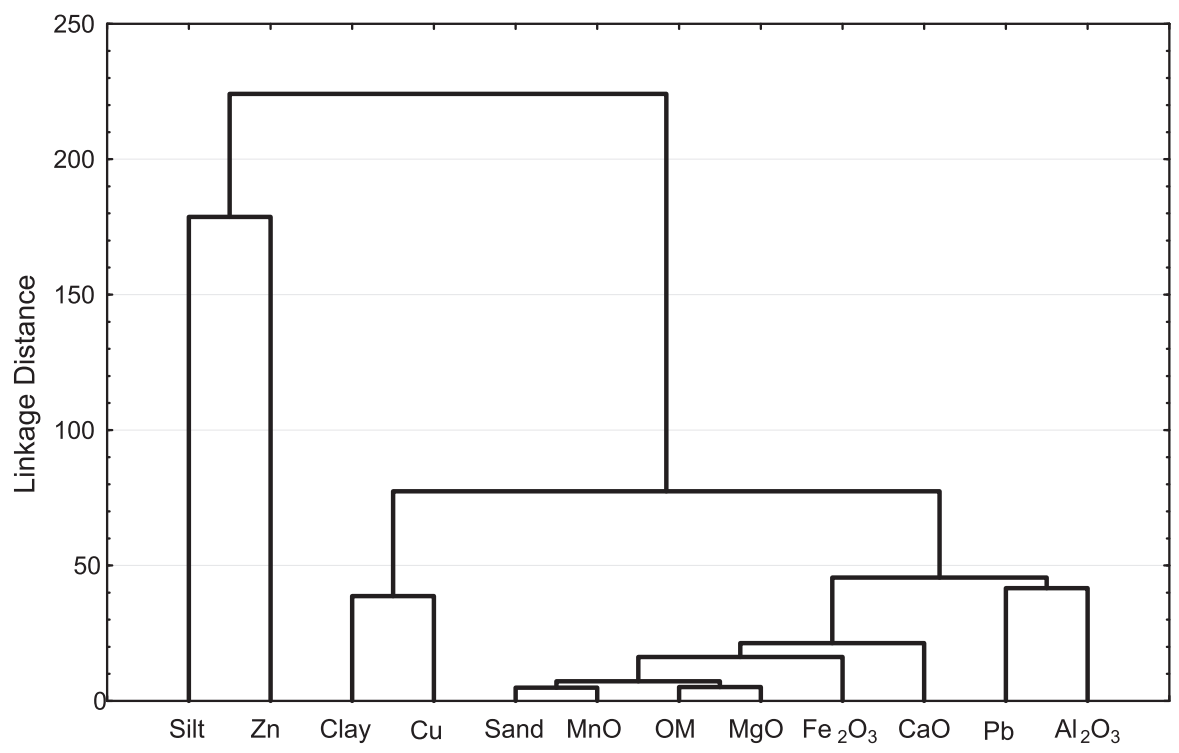

Fig. 11. Dendrogram for the variables measured in the sediments

Metrics used: pearson correlation; type of amalgamation: distant neighbours 
PRINCIPAL COMPONENT

ANALYSIS

PCA is a statistical technique used to identify important factors that explain the variance of a system (Ouyang, 2005). This analysis was performed to evaluate the possible provenance of trace metals, for which three factors explain $82 \%$ of system characteristics (Table 4). Upon application of the varimax rotation function for each factor, interpretation can be given, and statistical loads were determined.

The first factor showed three significant variables that explain $39 \%$ of the variance. The $\mathrm{Al}_{2} \mathrm{O}_{3}$ and $\mathrm{Fe}_{2} \mathrm{O}_{3}$ contents in the sediments are primarily of terrigenous origin, derived by the weathering of rocks mainly composed of aluminosilicates (Ramos-Vázquez et al., 2017). This first factor was accordingly designated as "terrigenous input" and was supported both by the Pearson correlation analyses and the association of the main group in cluster analysis. The loading of $\mathrm{Zn}$ with $\mathrm{Al}_{2} \mathrm{O}_{3}$ and $\mathrm{Fe}_{2} \mathrm{O}_{3}$ contents in factor 1 also indicates the association of $\mathrm{Zn}$ with aluminosilicates.

The second factor also provided three significant variables, explaining $30 \%$ of sediment characteristics such as the quantity of sand, silt, and clay. Texturally, the sediments are classified as clayey silt, which was homogeneous, and did not show a significant difference between the continental shelf and slope areas or with respect to water depth (Fig. 12).

In the third factor, two significant observable variables explain $13 \%$ of the characteristics of the system, i.e., the percentage of $\mathrm{OM}$ and $\mathrm{Cu}$ concentrations. $\mathrm{Cu}$ is of lithogenic origin rather than being associated with another source, which may be the reason that factor 3 , did not explain the significance of these variables (Table 4). However, through the correlation matrix, it can be inferred that the significant loads of these variables in both statistical methods are a result of the absence of affinity between $\mathrm{Cu}$ and $\mathrm{OM}$. Thus, OM did not capture this metal or form chelates with it.

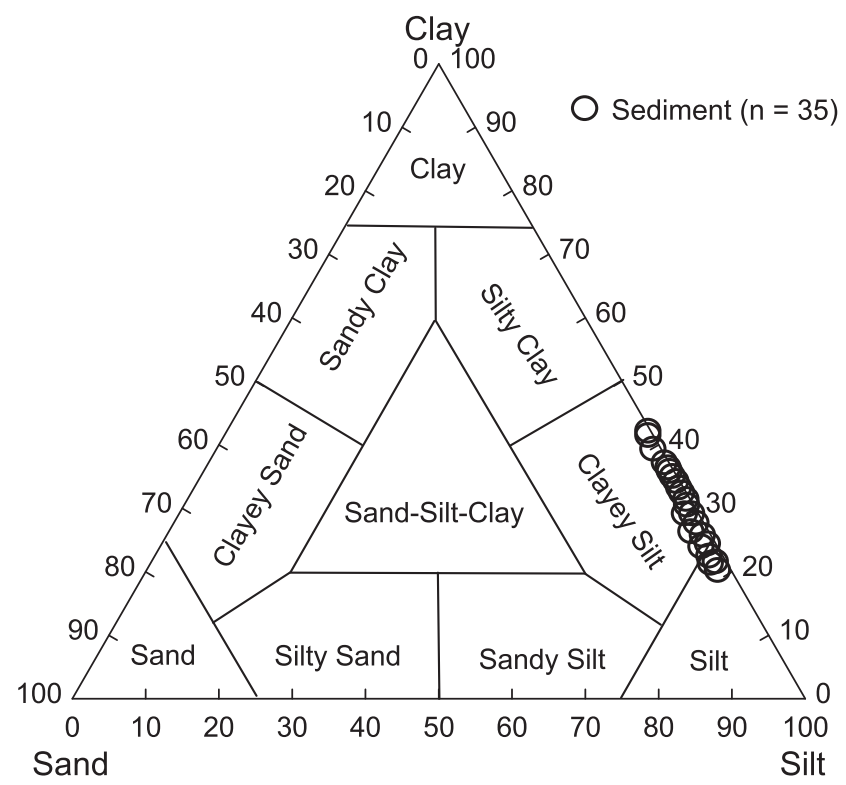

Fig. 12. Sand-silt-clay ternary diagram for the surficial sediments, NW Gulf of Mexico (modified after Shepard, 1954)
Factor analysis through main components, varimax rotation; significant loads $>0.70$

\begin{tabular}{|c|c|c|c|}
\hline Variables & Factor 1 & Factor 2 & Factor 3 \\
\hline $\mathrm{Al}_{2} \mathrm{O}_{3}$ & 0.790514 & 0.132282 & 0.210483 \\
\hline $\mathrm{CaO}$ & 0.403417 & 0.336511 & -0.2111251 \\
\hline $\mathrm{Fe}_{2} \mathrm{O}_{3}$ & 0.950813 & -0.181918 & 0.050831 \\
\hline $\mathrm{MgO}$ & 0.555961 & -0.287189 & 0.323296 \\
\hline $\mathrm{MnO}$ & -0.008650 & 0.020346 & 0.189308 \\
\hline $\mathrm{Pb}$ & 0.571065 & 0.305382 & 0.541147 \\
\hline $\mathrm{Cu}$ & 0.087294 & -0.162583 & -0.927810 \\
\hline $\mathrm{Zn}$ & 0.977789 & 0.011312 & -0.035203 \\
\hline Sand & -0.402557 & 0.790460 & -0.046612 \\
\hline Silt & 0.075502 & 0.965295 & 0.128449 \\
\hline Clay & -0.027445 & -0.978439 & -0.114173 \\
\hline$\%$ OM & 0.343190 & 0.007837 & 0.819451 \\
\hline Variance & 3.413190 & 2.766915 & 2.009526 \\
\hline$\%$ factor & 39.09824 & 29.54873 & 13.24934 \\
\hline$\%$ accumulated & 39.09824 & 68.64698 & 81.89631 \\
\hline
\end{tabular}

\section{HEAVY METAL CONTAMINATION}

\section{ENRICHMENT FACTOR}

A number of researchers have proposed the use of Enrichment factors (EF) to quantify the degree of anthropogenic influence in sediments (Selvaraj et al., 2004; Acevedo et al., 2006; Armstrong-Altrin et al., 2015a; Khan et al., 2017; Anaya-Gregorio et al., 2018), which can be calculated according to the formulae:

$$
E F=(M / A I)_{\text {sample }} /(M / A I)_{\text {crust }} \text {, }
$$

where: $\mathrm{M}$ is the value of analysed metal concentration (Wedepohl, 1995).

Among other major elements, we preferred $\mathrm{Al}_{2} \mathrm{O}_{3}$ content as a reference for normalization, because $\mathrm{Al}_{2} \mathrm{O}_{3}$ is considered as an immobile element, which represents the clay fraction in sediment (Prabakaran et al., 2019). If an enrichment factor is equal to one, the metals are considered as a natural source, if it is $>2$ it suggests an anthropogenic input. EF values are calculated based on average UCC concentrations (Taylor and McLennan, 1985) for the elements $\mathrm{Ba}, \mathrm{Co}, \mathrm{Cu}, \mathrm{Cr}, \mathrm{Ni}, \mathrm{Pb}, \mathrm{Sr}$, $\mathrm{V}$, and $\mathrm{Zn}$. The EF values are lower than 2 , which indicate that there is no significant anthropogenic input (Table 5). This corroborates with our interpretations based on statistical methods; neither enriched nor moderately enriched, and metal concentration was equal to the values expected under natural circumstances. 
Enrichment Factor (EF; Wedepohl, 1995) values for the surficial sediments, NW Gulf of Mexico, calculated based on average UCC values (Taylor and McLennan, 1985)

\begin{tabular}{|c|c|c|c|c|c|c|c|c|c|}
\hline Sample & $\mathrm{Ba}$ & Co & $\mathrm{Cu}$ & $\mathrm{Cr}$ & $\mathrm{Ni}$ & $\mathrm{Pb}$ & $\mathrm{Sr}$ & $\mathrm{V}$ & $\mathrm{Zn}$ \\
\hline 1 & 1.15 & 1.22 & 1.79 & 2.24 & 0.80 & 1.60 & 0.67 & 1.42 & 1.69 \\
\hline 2 & 0.74 & 0.66 & 1.26 & 0.94 & 0.67 & 1.37 & 0.52 & 1.28 & 1.53 \\
\hline 3 & 0.58 & 0.54 & 1.10 & 0.97 & 0.63 & 1.14 & 0.47 & 1.23 & 1.41 \\
\hline 4 & 0.65 & 0.71 & 1.32 & 0.90 & 0.75 & 1.41 & 0.52 & 1.30 & 1.60 \\
\hline 5 & 0.86 & 1.22 & 2.15 & 0.90 & 1.22 & 1.30 & 1.77 & 1.48 & 1.81 \\
\hline 6 & 0.93 & 1.42 & 2.61 & 1.06 & 1.39 & 1.25 & 1.73 & 1.69 & 1.96 \\
\hline 7 & 0.73 & 0.88 & 1.52 & 0.98 & 0.92 & 1.42 & 0.73 & 1.55 & 1.82 \\
\hline 8 & 0.62 & 0.86 & 1.26 & 0.88 & 0.74 & 1.29 & 0.84 & 1.31 & 1.58 \\
\hline 9 & 0.65 & 0.60 & 1.10 & 1.11 & 0.61 & 1.08 & 0.39 & 1.15 & 1.37 \\
\hline 10 & 0.96 & 0.87 & 1.41 & 1.00 & 0.75 & 1.47 & 0.48 & 1.37 & 1.74 \\
\hline 11 & 0.88 & 0.76 & 1.45 & 1.25 & 0.77 & 1.65 & 0.52 & 1.41 & 1.73 \\
\hline 12 & 0.61 & 0.63 & 1.11 & 0.87 & 0.61 & 1.22 & 0.34 & 1.12 & 1.38 \\
\hline 13 & 0.65 & 0.76 & 1.41 & 1.33 & 0.83 & 1.25 & 0.88 & 1.45 & 1.66 \\
\hline 14 & 0.73 & 0.88 & 1.47 & 0.97 & 0.97 & 1.15 & 0.83 & 1.56 & 1.82 \\
\hline 15 & 0.89 & 1.22 & 2.03 & 0.88 & 1.21 & 1.22 & 1.51 & 1.46 & 1.81 \\
\hline 16 & 0.71 & 1.03 & 1.78 & 0.77 & 1.04 & 1.03 & 1.35 & 1.25 & 1.60 \\
\hline 17 & 0.55 & 0.72 & 1.13 & 0.88 & 0.68 & 1.05 & 0.57 & 1.10 & 1.36 \\
\hline 18 & 0.65 & 0.90 & 1.46 & 1.15 & 0.83 & 1.32 & 0.49 & 1.35 & 1.76 \\
\hline 19 & 0.70 & 0.75 & 1.35 & 0.96 & 0.79 & 1.71 & 0.56 & 1.44 & 1.76 \\
\hline 20 & 0.83 & 0.67 & 1.32 & 0.92 & 0.67 & 1.47 & 0.51 & 1.37 & 1.61 \\
\hline 21 & 0.92 & 0.91 & 1.44 & 0.95 & 0.73 & 1.44 & 0.67 & 1.17 & 1.69 \\
\hline 22 & 0.77 & 0.98 & 1.38 & 1.46 & 0.78 & 1.61 & 0.50 & 1.28 & 1.77 \\
\hline 23 & 0.67 & 0.84 & 1.41 & 0.88 & 0.78 & 1.62 & 0.58 & 1.38 & 1.69 \\
\hline 24 & 0.63 & 0.62 & 1.35 & 0.93 & 0.74 & 1.18 & 0.63 & 1.25 & 1.57 \\
\hline 25 & 0.84 & 0.95 & 1.79 & 1.22 & 1.02 & 1.10 & 1.17 & 1.41 & 1.72 \\
\hline 26 & 0.82 & 0.94 & 1.78 & 0.86 & 0.98 & 1.09 & 1.19 & 1.30 & 1.70 \\
\hline 27 & 0.72 & 0.82 & 1.40 & 1.01 & 0.74 & 1.37 & 0.51 & 1.21 & 1.58 \\
\hline 28 & 0.70 & 0.77 & 1.30 & 1.28 & 0.69 & 1.34 & 0.45 & 1.12 & 1.54 \\
\hline 29 & 0.79 & 0.79 & 1.47 & 1.73 & 0.78 & 1.44 & 0.55 & 1.37 & 1.67 \\
\hline 30 & 0.74 & 0.97 & 1.44 & 0.90 & 0.72 & 1.30 & 1.94 & 1.23 & 1.58 \\
\hline 31 & 0.80 & 0.92 & 1.51 & 0.94 & 0.77 & 1.37 & 0.69 & 1.12 & 1.61 \\
\hline 32 & 0.68 & 0.86 & 1.46 & 1.04 & 0.69 & 1.57 & 0.69 & 1.16 & 1.64 \\
\hline 33 & 0.65 & 0.86 & 1.40 & 0.94 & 0.72 & 1.39 & 0.39 & 1.27 & 1.58 \\
\hline 34 & 0.58 & 0.69 & 1.25 & 0.76 & 0.71 & 1.32 & 0.60 & 1.09 & 1.45 \\
\hline 35 & 0.75 & 0.94 & 1.73 & 0.88 & 0.95 & 1.45 & 1.21 & 1.21 & 1.65 \\
\hline Mean & $0.75 \pm 0.1$ & $0.86 \pm 0.2$ & $1.5 \pm 0.3$ & $1.1 \pm 0.3$ & $0.8 \pm 0.2$ & $1.3 \pm 0.2$ & $0.8 \pm 0.4$ & $1.3 \pm 0.1$ & $1.6 \pm 0.1$ \\
\hline
\end{tabular}

\section{GEO-ACCUMULATION INDEX}

Geo-accumulation index $\left(\mathrm{I}_{\text {geo }}\right)$ can be calculated by an equation, $\log _{2}\left(C_{n} / 1.5 \times B_{n}\right)$ (Müller, 1969, 1979), where $C_{n}$ is the measured concentration of the metal " $n$ " in the sediment sample, $B_{n}$ is the geochemical background concentration of metal "n". The $I_{\text {geo }}$ value of 1.5 is a factor that considers possible variability generated by lithological variations. The $I_{\text {geo }}$ consists of seven grades, i.e. Class $0\left(I_{\text {geo }}=<0\right.$, practically uncontaminated), Class $1\left(I_{\text {geo }}=\right.$ $<1$, uncontaminated to moderately contaminated), Class $2\left(I_{\text {geo }}=\right.$ between 1 and 2; moderately contaminated), Class $3\left(I_{\text {geo }}=2-3\right.$, moderately to highly contaminated), Class 4 (Igeo $=3-4$, highly contaminated), Class $5\left(I_{\text {geo }}=4-5\right.$, highly to extremely contami- 
Geo-accumulation Index ( $I_{\text {geos }}$; Müller, 1979) values for the surficial sediments, NW Gulf of Mexico, calculated based on average UCC values (Taylor and McLennan, 1985)

\begin{tabular}{|c|c|c|c|c|c|c|c|c|c|}
\hline Sample & $\mathrm{Ba}$ & Co & $\mathrm{Cu}$ & $\mathrm{Cr}$ & $\mathrm{Ni}$ & $\mathrm{Pb}$ & $\mathrm{Sr}$ & V & $\mathrm{Zn}$ \\
\hline 1 & -1.06 & -0.97 & -0.42 & -0.10 & -1.58 & -0.58 & -1.85 & -0.76 & -0.51 \\
\hline 2 & -1.03 & -1.21 & -0.27 & -0.69 & -1.19 & -0.15 & -1.56 & -0.25 & 0.01 \\
\hline 3 & -1.25 & -1.35 & -0.32 & -0.52 & -1.14 & -0.28 & -1.57 & -0.17 & 0.03 \\
\hline 4 & -1.21 & -1.09 & -0.18 & -0.73 & -1.00 & -0.09 & -1.54 & -0.21 & 0.10 \\
\hline 5 & -1.27 & -0.77 & 0.06 & -1.21 & -0.76 & -0.67 & -0.23 & -0.48 & -0.20 \\
\hline 6 & -1.20 & -0.58 & 0.29 & -1.01 & -0.62 & -0.77 & -0.30 & -0.34 & -0.12 \\
\hline 7 & -1.25 & -0.97 & -0.18 & -0.81 & -0.92 & -0.28 & -1.24 & -0.16 & 0.07 \\
\hline 8 & -1.34 & -0.87 & -0.32 & -0.83 & -1.09 & -0.28 & -0.91 & -0.26 & 0.01 \\
\hline 9 & -1.08 & -1.21 & -0.32 & -0.32 & -1.19 & -0.35 & -1.82 & -0.26 & -0.01 \\
\hline 10 & -0.83 & -0.97 & -0.27 & -0.77 & -1.19 & -0.21 & -1.83 & -0.32 & 0.03 \\
\hline 11 & -0.99 & -1.21 & -0.27 & -0.48 & -1.19 & -0.09 & -1.75 & -0.32 & -0.02 \\
\hline 12 & -1.15 & -1.09 & -0.27 & -0.64 & -1.14 & -0.15 & -1.98 & -0.27 & 0.03 \\
\hline 13 & -1.44 & -1.21 & -0.32 & -0.41 & -1.09 & -0.50 & -1.01 & -0.28 & -0.09 \\
\hline 14 & -1.24 & -0.97 & -0.23 & -0.83 & -0.83 & -0.58 & -1.06 & -0.15 & 0.07 \\
\hline 15 & -1.14 & -0.67 & 0.06 & -1.15 & -0.69 & -0.67 & -0.37 & -0.42 & -0.11 \\
\hline 16 & -1.30 & -0.77 & 0.02 & -1.18 & -0.76 & -0.77 & -0.37 & -0.49 & -0.13 \\
\hline 17 & -1.37 & -0.97 & -0.32 & -0.67 & -1.04 & -0.42 & -1.31 & -0.36 & -0.05 \\
\hline 18 & -1.44 & -0.97 & -0.27 & -0.62 & -1.09 & -0.42 & -1.85 & -0.38 & -0.01 \\
\hline 19 & -1.30 & -1.21 & -0.37 & -0.85 & -1.14 & -0.03 & -1.64 & -0.27 & 0.02 \\
\hline 20 & -1.03 & -1.35 & -0.37 & -0.89 & -1.34 & -0.21 & -1.74 & -0.32 & -0.08 \\
\hline 21 & -1.07 & -1.09 & -0.42 & -1.03 & -1.40 & -0.42 & -1.52 & -0.73 & -0.20 \\
\hline 22 & -1.21 & -0.87 & -0.37 & -0.29 & -1.19 & -0.15 & -1.84 & -0.48 & -0.01 \\
\hline 23 & -1.30 & -0.97 & -0.23 & -0.92 & -1.09 & -0.03 & -1.52 & -0.26 & 0.03 \\
\hline 24 & -1.32 & -1.35 & -0.23 & -0.77 & -1.09 & -0.42 & -1.32 & -0.34 & -0.01 \\
\hline 25 & -1.15 & -0.97 & -0.06 & -0.62 & -0.87 & -0.77 & -0.67 & -0.41 & -0.12 \\
\hline 26 & -1.17 & -0.97 & -0.06 & -1.10 & -0.92 & -0.77 & -0.64 & -0.51 & -0.12 \\
\hline 27 & -1.29 & -1.09 & -0.32 & -0.79 & -1.24 & -0.35 & -1.79 & -0.53 & -0.15 \\
\hline 28 & -1.21 & -1.09 & -0.32 & -0.35 & -1.24 & -0.28 & -1.86 & -0.55 & -0.08 \\
\hline 29 & -1.22 & -1.21 & -0.32 & -0.09 & -1.24 & -0.35 & -1.75 & -0.42 & -0.13 \\
\hline 30 & -1.48 & -1.09 & -0.53 & -1.21 & -1.52 & -0.67 & -0.09 & -0.76 & -0.39 \\
\hline 31 & -1.29 & -1.09 & -0.37 & -1.05 & -1.34 & -0.50 & -1.50 & -0.80 & -0.28 \\
\hline 32 & -1.42 & -1.09 & -0.32 & -0.81 & -1.40 & -0.21 & -1.41 & -0.65 & -0.15 \\
\hline 33 & -1.38 & -0.97 & -0.27 & -0.85 & -1.24 & -0.28 & -2.11 & -0.41 & -0.09 \\
\hline 34 & -1.32 & -1.09 & -0.23 & -0.94 & -1.04 & -0.15 & -1.27 & -0.42 & -0.01 \\
\hline 35 & -1.30 & -0.97 & -0.10 & -1.08 & -0.96 & -0.35 & -0.61 & -0.61 & -0.16 \\
\hline Mean & $-1.2 \pm 0.1$ & $-1 \pm 0.2$ & $-0.2 \pm 0.2$ & $-0.8 \pm 0.3$ & $-1.1 \pm 0.2$ & $-0.4 \pm 0.2$ & $-1.3 \pm 0.6$ & $-0.4 \pm 0.2$ & $-0.1 \pm 0.1$ \\
\hline
\end{tabular}

nated). The $I_{\text {geo }}$ values calculated for the surficial sediments are $<0$ and within Class 0 (practically uncontaminated; Table 6 ). This interpretation is consistent with EF values, which indicates that the concentration of heavy metals in sediments is not due to an anthropogenic source.

\section{CONCLUSIONS}

1. The major element concentrations indicated that the sediments were derived from an intermediate rock composition, probably andesite located along the coastal areas of the NW Gulf of Mexico. 
2. The weathering indices demonstrated that the sediments were derived from moderately to highly weathered source area.

3. Major and trace element concentrations in the surface sediments are statistically shown to be of lithogenic origin, chiefly brought into the marine depositional environment by rivers. The Rio Bravo and Soto La Marina rivers played an important role in delivering sediments to the study area.

4. The $\mathrm{Cr}, \mathrm{Cu}$, and $\mathrm{V}$ contents also reveal that the sediments received a major contribution from intermediate source rocks. The $\mathrm{V} / \mathrm{Cr}, \mathrm{Ni} / \mathrm{Co}$, and $\mathrm{Cu} / \mathrm{Zn}$ ratios in sediments from the NW Gulf of Mexico are $<2,<5$, and $<1$, respectively, which support that these sediments were deposited in well-oxygenated conditions.

5. The EF for $\mathrm{Ba}, \mathrm{Co}, \mathrm{Cu}, \mathrm{Cr}, \mathrm{Ni}, \mathrm{Pb}, \mathrm{Sr}, \mathrm{V}$, and $\mathrm{Zn}$ are $<2$. This indicates a low probability of anthropogenic input, because they are neither enriched nor moderately enriched, and are similar to the values expected under natural circumstances. The statistical parameters also indicate the association of these elements with detrital constituents.
Acknowledgements. Financial support for this study was provided by the Instituto Nacional de Ecología y Cambio Climatico (INECC) as part of a long-term project "Marco ambiental de las condiciones oceanograficas en el sector NW de la ZEE de Mexico en el Golfo de Mexico (MARZEE)". JSA is grateful to the CONACyT Ciencia Básica (A1-S-21287) and Programa de Apoyo a Proyectos de Investigación e Innovación Tecnológica (IN106117) projects. The authors express their gratitude to the crew members of the "R/N Justo Sierra" and the scientific party that participated in this project. We are thankful to M.A. Ramos-Vázquez, Posgrado en Ciencias del Mar y Limnología for the help in statistical analysis and in calculating the Enrichment Factor and Geo-accumulation index. Thanks are also extended to $C$. E. García-Ruelas for providing invaluable technical support and field assistance during the course of this study. We are also grateful to C. Linares-López, T. Hernández Trevioñ, and L.E. Gómez Lizárraga for mineral identification through SEM and SEM-EDS. We extend our sincere thanks to the Journal Reviewers N. Ramasamy and M. Jayagopal for their extensive comments, which improved our presentation significantly. Technical Editing by E. Dąbrowska-Jędrusik is highly appreciated.

\section{REFERENCES}

Acevedo, D., Jiménez, B., Rodríguez, C., 2006. Trace metals in sediments of two estuarine lagoons from Puerto Rico. Environmental Pollution, 141: 336-342.

Anaya-Gregorio, A., Armstrong-Altrin, J.S., Machain-Castillo, M.L., Montiel-García, P.C., Ramos-Vázquez, M.A., 2018. Textural and geochemical characteristics of late Pleistocene to Holocene fine-grained deep-sea sediment cores (GM6 and GM7), recovered from southwestern Gulf of Mexico. Journal of Palaeogeography, 7: 253-271.

Armstrong-Altrin, J.S., 2009. Provenance of sands from Cazones, Acapulco, and Bahía Kino beaches, Mexico. Revista Mexicana de Ciencias Geologicas, 26: 764-782.

Armstrong-Altrin, J.S., 2015. Evaluation of two multi-dimensional discrimination diagrams from beach and deep sea sediments from the Gulf of Mexico and their application to Precambrian clastic sedimentary rocks. International Geology Review, 57: 1446-1461.

Armstrong-Altrin, J.S., Machain-Castillo, M.L., 2016. Mineralogy, geochemistry, and radiocarbon ages of deep sea sediments from the Gulf of Mexico, Mexico. Journal of South American Earth Sciences, 71: 182-200.

Armstrong-Altrin, J.S., Natalhy-Pineda, O., 2014. Microtextures of detrital sand grains from the Tecolutla, Nautla, and Veracruz beaches, western Gulf of Mexico, Mexico: implications for depositional environment and palaeoclimate. Arabian Journal of Geosciences, 7: 4321-4333.

Armstrong-Altrin, J.S, Lee, Y.I., Verma, S.P., Ramasamy, S., 2004. Geochemistry of sandstones from the upper Miocene Kudankulam Formation, southern India: implications for provenance, weathering, and tectonic setting. Journal of Sedimentary Research, 74: 285-297.

Armstrong-Altrin, J.S., Lee, Y.I., Kasper-Zubillaga, J.J., Carranza-Edwards, A., Garcia, D., Eby, N., Balaram, V., Cruz-Ortiz, N., 2012. Geochemistry of beach sands along the Western Gulf of Mexico, Mexico: implication for provenance. Chemie der Erde Geochemistry, 72: 345-362.

Armstrong-Altrin, J.S., Nagarajan, R., Madhavaraju, J., Rosalez-Hoz, L., Lee, Y.I., Balaram, V., Cruz-Martinez, A., AvilaRamirez, G., 2013. Geochemistry of the Jurassic and upper Cretaceous shales from the Molango Region, Hidalgo, Eastern Mexico: implications of source-area weathering, provenance, and tectonic setting. Comptes Rendus Geoscience, 345: 185-202.
Armstrong-Altrin, J.S., Nagarajan, R., Lee, Y.I., Kasper-Zubillaga, J.J., Córdoba-Saldaña, L.P., 2014. Geochemistry of sands along the San Nicolás and San Carlos beaches, Gulf of California, Mexico: implication for provenance. Turkish Journal of Earth Sciences, 23: 533-558.

Armstrong-Altrin, J.S., Machain-Castillo, M.L., Rosales-Hoz, L., Carranza-Edwards, A., Sanchez-Cabeza, J.A., Ruíz-Fernández, A.C., 2015a. Provenance and depositional history of continental slope sediments in the Southwestern Gulf of Mexico unraveled by geochemical analysis. Continental Shelf Research, 95: $15-26$.

Armstrong-Altrin, J.S., Nagarajan, R., Balaram, V., Natalhy-Pineda, O., 2015b. Petrography and geochemistry of sands from the Chachalacas and Veracruz beach areas, western Gulf of Mexico, Mexico: constraints on provenance and tectonic setting. Journal of South American Earth Sciences, 64: 199-216.

Armstrong-Altrin, J.S., Lee, Y.I., Kasper-Zubillaga, J.J., Trejo-Ramírez, E., 2017. Mineralogy and geochemistry of sands along the Manzanillo and El Carrizal beach areas, southern Mexico: implications for palaeoweathering, provenance, and tectonic setting. Geological Journal, 52: 559-582.

Armstrong-Altrin, J.S., Ramos-Vázquez, M.A., Zavala-León, A.C., Montiel-García, P.C., 2018. Provenance discrimination between Atasta and Alvarado beach sands, western Gulf of Mexico, Mexico: constraints from detrital zircon chemistry and U-Pb geochronology. Geological Journal, 53: 2824-2848.

Arora, A., Banerjee, S., Dutta, S., 2015. Black shale in late Jurassic Jhuran Formation of Kutch. Journal of the Geological Society of India, 85: 265-278.

Bansal, U., Banerjee, S., Ruidas, D.K., Pande, K., 2018. Origin and geochemical characterization of the glauconites in the upper Cretaceous Lameta Formation, Narmada Basin, central India. Journal of Palaeogeography, 7: 99-116.

Basu, A., 2017. Evolution of siliciclastic provenance inquiries: a critical appraisal. In: Sediment Provenance (ed. Rajat Mazumder): 5-23. Elsevier Amsterdam, Netherlands. Chapter 2. doi:10.1016/B978-0-12-803386-9.00002-2

Botello, A.V., Soto, L.A., Ponce-Veléz, G., Villanueva, F.S., 2015. Baseline for PAHs and metals in NW Gulf of Mexico related to the Deepwater Horizon oil spill. Estuarine, Coastal and Shelf Science, 156: 124-133. 
Bracciali, L., Marroni, M., Pandolfi, L., Rocchi, S., 2007. Geochemistry and petrography of western Tethys Cretaceous sedimentary covers (Corsica and Northern Apennines): from source areas to configuration of margins. In: Sedimentary provenance and petrogenesis: Perspectives from petrography and geochemistry, vol. 420 (eds. J. Arribas, S. Critelli, M.J. Johnsson): 73-93. Geological Society of America Special Paper.

Carrasco-Núñez, G., Righter, K., Chesley, J., Siebert, L., Aranda-Gómez, J.J., 2005. Contemporaneous eruption of calc-alkaline and alkaline lavas in a continental arc (Eastern Mexican Volcanic Belt): chemically heterogeneous but isotopically homogeneous source. Contributions to Mineralogy and Petrology, 150: 423-440.

Chaudhuri, A., Banerjee, S., Le Pera, E., 2018. Petrography of Middle Jurassic to early Cretaceous sandstones in the Kutch Basin, western India: implications on provenance and basin evolution. Journal of Palaeogeography, 7: 2.

Chester, R., 2000. Marine Biogeochemistry. Blackwell Science Great Britain.

Cullers, R.L., 2000. The geochemistry of shales, siltstones and sandstones of Pennsylvanian-Permian age, Colorado, USA: implications for provenance and metamorphic studies. Lithos, 51: 181-203.

Cullers. R.L., Basu, A., Suttner, L.J., 1988. Geochemical signature of provenance in sand-size material in soils and stream sediments near the Tobacco Root batholith, Montana, USA. Chemical Geology, 70: 335-348.

Dill, H., 1986. Metallogenesis of early Paleozoic graptolite shales from the Graefenthal Horst (northern Bavaria-Federal Republic of Germany). Economic Geology, 81: 889-903.

Dill, H., Teshner, M., Wehner, H., 1988. Petrography, inorganic and organic geochemistry of Lower Permian Carboniferous fan sequences ("Brandschiefer Series") FRG: constraints to their paleogeography and assessment of their source rock potential. Chemical Geology, 67: 307-325.

Dypvik, H., 1984. Geochemical compositions and depositional conditions of Upper Jurassic and Lower Cretaceous Yorkshire clays, England. Geological Magazine, 121: 489-504.

Etemad-Saeed, N., Hosseini-Barzi, M., Adabi, M.H, Sadeghi, A., Houshmandzadeh, A., 2015. Provenance of Neoproterozoic sedimentary basement of northern Iran, Kahar Formation. Journal of African Earth Sciences, 111: 54-75.

Fedo, C.M., Nesbitt, H.W., Young, G.M., 1995. Unraveling the effects of potassium metasomatism in sedimentary rocks and paleosols, with implications for paleoweathering conditions and provenance. Geology, 10: 921-924.

Gabrielli, P., Wegner, A., Petit, J.R., Delmonte, B., De Deckker, P., Gaspari, V., Fischer, H., Ruth, U., Kriews, M., Boutron, C., Cescon, P., Barbante, C., 2010. A major glacial-interglacial change in aeolian dust composition inferred from rare earth elements in Antarctic ice. Quaternary Science Reviews, 29: 265-273.

Garver, J.I., Royce, P.R., Smick, T.A., 1996. Chromium and nickel in shale of the Taconic Foreland: a case study for the provenance of fine-grained sediments with an ultramafic source. Journal of Sedimentary Research, 66: 100-106.

Hair, J.F., Anderson, R.E., Taham, R.L., William, C.B., 2001. Análisis Multivariante. 5a Ed. Prentice Hall: 794.

Hallberg, R.O., 1976. A geochemical method for investigation of palaeoredox conditions in sediments. Ambio Special Report, 4: 139-147.

Harnois, L., 1988. The CIW index: a new chemical index of weathering. Sedimentary Geology, 55: 319-322.

Hernández-Hinojosa, V., Montiel-García, P.C., Armstrong-Altrin, J.S., Nagarajan, R., Kasper-Zubillaga, J.J., 2018. Textural and geochemical characteristics of beach sands along the western Gulf of Mexico, Mexico. Carpathian Journal of Earth and Environmental Sciences, 13: 161-174.

Herron, M.M., 1988. Geochemical classification of terrigenous sands and shales from core or log data. Journal of Sedimentary Petrology, 58: 820-829.
Hou, Q., Mou, C., Wang, Q., Tan, Z., 2017. Provenance and tectonic setting of the Early and Middle Devonian Xueshan Formation, the North Qilian Belt, China. Geological Journal 1-19 doi: 10.1002/gj.2963

Hu, G., Hu, W-X., Cao, J., Yang, R-F., Chen, H-Y., Zhao, D-F., Pang, Q., Wang, H-Y., Tan, X-C., 2017. The distribution, hydrocarbon potential, and development of the Lower Cretaceous black shales in coastal southeastern China. Journal of Palaeogeography, 6: 333-351.

Hua, G., Yuansheng, D., Lian, Z., Jianghai, Y., Hu, H., Min, L., Yuan, W., 2013. Trace and rare earth elemental geochemistry of carbonate succession in the Middle Gaoyuzhuang Formation, Pingquan Section: Implications for Early Mesoproterozoic Ocean redox conditions. Journal of Palaeogeography, 2: 209-221.

Jones, B., Manning, D.C., 1994. Comparison of geochemical indices used for the interpretation of paleo-redox conditions in Ancient mudstones. Chemical Geology, 111: 111-129.

Kasper-Zubillaga, J.J., Armstrong-Altrin, J.S., Carranza-Edwards, A., Morton-Bermea, O., Lozano-Santa-Cruz, R., 2013. Control in beach and dune sands of the Gulf of Mexico and the role of nearby rivers. International Journal of Geosciences, 4: 1157-1174.

Kasper-Zubillaga, J.J., Arellano-Torres, E., Armstrong-Altrin, J.S., 2019. Physical degradation and early diagenesis in foraminiferal tests after subaerial exposure in terrigenous-depleted beaches of Yucatan, Mexico. Carbonates and Evaporites, doi: https://doi.org/10.1007/s13146-019-00485-4

Kelepile, T., Betsi, T.B., Franchi, F., Shemang, E., Suh, C.E., 2017. Provenance and tectonic setting of the Neoproterozoic clastic rocks hosting the Banana Zone $\mathrm{Cu}-\mathrm{Ag}$ mineralisation, northwest Botswana. Journal of African Earth Sciences, 129: 853-869.

Khan, R., Rouf, M.A., Das, S., Tamin, U., Naher, K., Podder, J., Hossain, S.M., 2017. Spatial and multi-layered assessment of heavy metals in the sand of Coxs-Bazar beach of Bangladesh. Regional Studies in Marine Science, 16: 171-180.

Le Bas, M.J., Le Maitre, R.W., Streckeisen, A., Zanettin, B., 1986. A chemical classification of volcanic rocks based on the total alkali-silica diagram. Journal of Petrology, 27: 745-750.

Lee, Y.I., 2009. Geochemistry of shales of the Upper Cretaceous Hayang Group, SE Korea: implications for provenance and source weathering at an active continental margin. Sedimentary Geology, 215: 1-12.

Lin, C-M., Zhang, X., Zhang, N., Chen, S-Y, Liu, M., 2014. Provenance records of the north Jiangsu Basin, east China: zircon $\mathrm{U}-\mathrm{Pb}$ geochronology and geochemistry from the Paleogene Dainan Formation in the Gaoyou Sag. Journal of Palaeogeography, 3: 99-114.

Liu, B., Jin, H.L., Sun, L.Y., Sun, Z., Niu, Q.H., Zhang, C.X., 2016. Geochemical characteristics of Holocene aeolian deposits and their environmental significance in the Mu Us desert, northern China. Geological Journal, 51: 325-337.

Long, E.R., Macdonald, D.D., Smith, S.L., 1995. Incidence of adverse biological effects within ranges of chemical concentrations in marine and estuarine sediments. Environmental Management, 1: 81-97.

Ma, K., Hu, S., Wang, T., Zhang, B., Qin, S., Shi, S., Wang, K., Qingyu, H., 2017. Sedimentary environments and mechanisms of organic matter enrichment in the Mesoproterozoic Hongshuizhuang Formation of northern China. Palaeogeography, Paleoclimatology, Palaeoecology, 475: 176-187.

Ma, M., Chen, G., Lyu, C., Zhang, G., Li, C., Yan, Y., Ma, Z., 2019. The formation and evolution of the paleo-Pearl River and its influence on the source of the northern South China Sea. Marine and Petroleum Geology, 106: 171-189.

Madhavaraju, J., 2015. Geochemistry of Campanian-Maastrichtian sedimentary rocks in the Cauvery Basin, South India: Constrains on paleoweathering, provenance and end Cretaceous environments. Chemostratigraphy: Concepts, Techniques and Applications (ed. M. Ramkumar): 185-214. Elsevier Special Volume. 
Madhavaraju, J., Lee, Y.I., 2010. Influence of Deccan Volcanism in the sedimentary rocks of Late Maastrichtian-Danian age of Cauvery Basin, Southeastern India: constraints from Geochemistry. Current Science, 98: 528-537.

Madhavaraju, J., Tom, M., Lee, Y.I., Balaram, V., Ramasamy, S., Carranza-Edwards, A., Ramachandran, A., 2016. Provenance and tectonic settings of sands from Puerto Peñasco, Desemboque and Bahia Kino beaches, Gulf of California, Sonora, Mexico. Journal of South American Earth Sciences, 71: 262-275.

Madhavaraju, J., Pacheco-Olivas, S.A., González-León, C.M., Espinoza-Maldonado, I.G., Sanchez-Medrano, P.A., Villanueva-Amadoz, U., Monreal, R., Pi-Puig, T., Ramírez-Montoya, E., Grijalva-Noriega, F.J., 2017. Mineralogy and geochemistry of the Lower Cretaceous siliciclastic rocks of the Morita Formation, Sierra San José section, Sonora, Mexico. Journal of South American Earth Sciences, 76: 397-411.

Madhavaraju, J., Saucedo-Samaniego, J.C., Loser, H., Espinoza-Maldonado, I.G., Solari, L., Monreal, R., Grijalva-Noriega, F.J., Jaques-Ayala, C., 2018. Detrital zircon record of Mesozoic volcanic arcs in the Lower Cretaceous Mural Limestone, Northwestern Mexico. Geological Journal: 1-25. https://doi.org/10.1002/gj.3315

Martinez, N.C., Murray, R.W., Thunel, R.C., Peterson, L.C., Muller-Karger, F., Lorenzoni, L., Astor, Y., Varela, R., 2010. Local and regional geochemical signatures of surface sediments from the Cariaco Basin and Orinoco Delta, Venezuela. Geology, 38: 159-162.

McLennan, S.M., Hemming, S., McDaniel, D.K., Hanson, G.N., 1993. Geochemical approaches to sedimentation, provenance, and tectonics. In: Processes Controlling the Composition of Clastic Sediments (eds. M.J. Johnsson and A. Basu): 21-40. Geological Society of America Special Paper.

Monreal-Gómez, M.A., Salas de León, D.A., 1990. Simulación de la circulación de la Bahía de Campeche. Geofísica Internacional, 29: 101-111.

Morford, J.L., Emerson, S., 1999. The geochemistry of redox sensitive trace metals in sediments. Geochimica et Cosmochimca Acta, 63: 1735-1750.

Müller, G., 1969. Index of geoaccumulation in sediments of the Rhine River. Geojournal, 2: 108-118.

Müller, G., 1979. Schwermetalle in den sedimenten des Rheins-Veranderungen seitt 1971. Umschan, 79: 778-783.

Murray, R.W., Leinen, M., 1996. Scavenged excess aluminum and its relationship to bulk titanium in biogenic sediment from the central equatorial Pacific Ocean. Geochimica et Cosmochimica Acta, 60: 3869-3878.

Nagarajan, R., Armstrong-Altrin, J.S., Kessler, F.L., Hidalgo-Moral, E.L., Dodge-Wan, D., Taib, N.I., 2015. Provenance and tectonic setting of Miocene siliciclastic sediments, Sibuti formation, northwestern Borneo. Arabian Journal of Geosciences, 8: 8549-8565.

Nagarajan, R., Armstrong-Altrin, J.S., Kessler, F.L., Jong, J., 2017. Petrological and geochemical constraints on provenance, paleo-weathering and tectonic setting of clastic sediments from the Neogene Lambir and Sibuti Formations, Northwestern Borneo. In: Sediment Provenanc (ed. Rajat Mazumder): 123-153 e. Elsevier Amsterdam, Netherlands. Chapter 7. doi:10.1016/B978-0-12-803386-9.00007-1

Ndjigui, P-D., Bayiga, E.C., Onana, V.L., Djenabou-Fadil, S., Ngono, G.S.A., 2019. Mineralogy and geochemistry of recent alluvial sediments from the Ngaye River watershed, northern Cameroon: implications for the surface processes and Au-PGE distribution. Journal of African Earth Sciences, 150: 136-157.

Nesbitt, H.W., Young, G.M., 1982. Early Proterozoic climate and plate motions inferred from major element chemistry of lutites. Nature, 299: 715-717

Nesbitt, H.W., Fedo, C.M., Young, G.M., 1997. Quartz and feldspar stability, steady and non-steady-state weathering, and petrogenesis of siliciclastic sands and muds. Journal of Geology, 105: 173-192.
Ortega-Gutierrez, F., Ruiz, J., Centeno-García, E., 1995. Oaxaquia, a Proterozoic microcontinent accreted to North America during the late Paleozoic. Geology, 23: 1127-1130.

Ouyang, Y., 2005. Evaluation of river water quality monitoring stations by principal component analysis. Water Research, 39: 2621-2635.

Paikaray, S., Banerjee, S., Mukherji, S., 2008. Geochemistry of shales from the Paleoproterozoic to Neoproterozoic Vindhyan Supergroup: implications on provenance, tectonics and paleoweathering. Journal of Asian Earth Sciences, 32: 34-48.

Pandey, S., Parcha, S.K., 2017. Provenance, tectonic setting and source-area weathering of the lower Cambrian sediments of the Parahio valley in the Spiti basin, India. Journal of Earth System Science, 126: 27

Parker, A., 1970. An index of weathering for silicate rocks. Geological Magazine, 107: 501-504.

Prabakaran, K., Nagarajan, R., Eswaramoorthi, S., Anandkumar, A., Franco, F.M., 2019. Environmental significance and geochemical speciation of trace elements in Lower Baram River sediments. Chemosphere, 219: 933-953.

Price, J.R., Velbel, M.A., 2003. Chemical weathering indices applied to weathering profiles developed on heterogeneous felsic metamorphic parent rocks. Chemical Geology, 202: 397-416.

Qiu, S., Zhu, Z., Yang, T., Wu, Y., Bai, Y., Ouyang, T., 2014. Chemical weathering of monsoonal eastern China: implications from major elements of topsoil. Journal of Asian Earth Sciences, 81: 77-90.

Ramachandran, A., Madhavaraju, J., Ramasamy, S., Lee, Y.I., Rao, S., Chawngthu, D.L., Velmurugan, K., 2016. Geochemistry of Proterozoic clastic rocks of the Kerur Formation of Kaladgi-Badami Basin, North Karnataka, South India: implications for paleoweathering and provenance. Turkish Journal of Earth Sciences, 25: 126-144.

Ramos-Vázquez, M., Armstrong-Altrin, J.S., Rosales-Hoz, L., Machain-Castillo, M.L., and Carranza-Edwards, A., 2017. Geochemistry of deep-sea sediments in two cores retrieved at the mouth of the Coatzacoalcos river delta, Western Gulf of Mexico, Mexico. Arabian Journal of Geosciences, 10: 148.

Ramos-Vázquez, M.A., Armstrong-Altrin, J.S., Machain-Castillo, M.L., Gío-Argáez, F.R. 2018. Foraminiferal assemblages, ${ }^{14} \mathrm{C}$ ages, and compositional variations in two sediment cores in the western Gulf of Mexico. Journal of South American Earth Sciences, 88: 480-496.

Riquier, L., Tribovillard, N., Averbuch, O., Devleeschouwer, X., Riboulleau, A., 2006. The late Frasnian Kellwasser horizons of the Harz Mountains (Germany): two oxygen-deficient periods resulting from different mechanisms. Chemical Geology, 233: 137-155.

Rosales-Hoz, L., Carranza-Edwards, A., Martínez-Serrano, R., Alatorre, M.A, Armstrong-Altrin, J.S., 2015. Textural and geochemical characteristics of marine sediments in the SW Gulf of Mexico: implications for source and seasonal change. Environmental Monitoring and Assessment, 187-205: 1-19.

Roser, B.P., Korsch, R.J., 1988. Provenance signatures of sandstone-mudstone suites determined using discrimination function analysis of major-element data. Chemical Geology, 67: 119-139.

Salas de León, D.A., Monreal-Gomez, M.A., Colunga-Enríquez, G., 1992. Hidrografía y circulación geostrófica en el sur de la Bahía de Campeche. Geofísica Internacional, 31: 315-323.

Salas-Monreal, D., Marin-Hernandez, M., Salas-Perez, J.J., Salas-de-Leon, D.A., Monreal-Gomez, M.A., Perez-España, H., 2018. Coral reef connectivity within the Western Gulf of Mexico. Journal of Marine Systems, 179: 88-99.

Schaaf, P., Stimac, J., Siebe, C., Macías, J.L., 2005. Geochemical evidence for mantle origin and crustal processes in volcanic rocks from Popocatépetl and surrounding monogenetic volcanoes, Central Mexico. Journal of Petrology, 46: 1243-1282.

Selvaraj, K., Ram, V., Szefer, P., 2004. Evaluation of metal contamination in coastal sediments Bay of Bengal, India: geochemical and statistical approaches. Marine Pollution Bulletin, 49: 174-185. 
Shaw, T.J., Geiskes, J.M., Jahnke, R.A., 1990. Early diagenesis in differing depositional environments: the response of transition metals in pore water. Geochimica et Cosmochimica Acta, 54: 1233-1246.

Shepard, F.P., 1954. Nomenclature based on sand-silt-clay ratios. Journal of Sedimentary Petrology, 24: 151-158.

Spalletti, L.A., Remírez, M.N., Sagasti, G., 2019. Geochemistry of aggradational - progradational sequence sets of the Upper Jurassic - Lower Cretaceous Vaca Muerta shales (Añelo area, Neuquén Basin, Argentina): Relation to changes in accommodation and marine anoxia. Journal of South American Earth Sciences, https://doi.org/10.1016/ j.jsames.2019.02.011

Taheri, A., Jafarzadeh, M., Armstrong-Altrin, J.S., Mirbagheri, S.R., 2018. Geochemistry of siliciclastic rocks from the Shemshak Group (Upper Triassic-Lower-Middle Jurassic), northeastern Alborz, northern Iran: implications for palaeoweathering, provenance, and tectonic setting. Geological Quarterly, 62 (3): 522-535.

Tamayo, J.L., 1991. Geografía Moderna de México, 11th ed. Trillas, México City.

Tapia-Fernandez, H.J., Armstrong-Altrin, J.S., Selvaraj, K., 2017. Geochemistry and U-Pb geochronology of detrital zircons in the Brujas beach sands, Campeche, Southwestern Gulf of Mexico, Mexico. Journal of South American Earth Sciences, 76: 346-361.

Tawfik, H.A., Ghandour, I.M., Maejima, W., Armstrong-Altrin, J.S., Abdel-Hameed, A-M.T., 2017. Petrography and geochemistry of the siliciclastic Araba Formation (Cambrian), east Sinai, Egypt: Implications for provenance, tectonic setting and source weathering. Geological Magazine, 154: 1-23.

Tawfik, H.A., Salah, M.K., Maejima, W., Armstrong-Altrin, J.S., Abdel-Hameed, A-M.T., Ghandour, M.M.E., 2018. Petrography and geochemistry of the Lower Miocene Moghra sandstones, Qattara Depression, north Western Desert, Egypt. Geological Journal, 53: 1938-1953.

Taylor, S.R., McLennan, S.M., 1985. The Continental Crust: its Composition and Evolution. Oxford, UK. Blackwell.

Tzifas, I.T., Papadopoulos, A., Misaelides, P., Godelitsas, A., GŘttlicher, J., Tsikos, H., Gamaletsos, P.N., Luvizotto, G. Karydas, A.G., Petrelli, M., Noli, F., Kantarelou, V., Kontofakas, A., Hatzidimitriou, A., 2019. New insights into mineralogy and geochemistry of allanite-bearing Mediterranean coastal sands from Northern Greece. Geochemistry, 79: 247-267.

Velmurugan, K., Madhavaraju, J., Balaram, V., Ramasamy, S., Ramachandran, A., Ramirez-Montoya, E., Saucedo-Samaniego, J.C., 2019. Provenance and tectonic setting of the clastic rocks of the Kerur Formation, Badami Group, Mohare area, Karnataka, India. In: Precambrian Crustal Evolution of India: Geological Evolution of the Precambrian Indian Shield (ed. M.E.A. Mondal): 239-269. Society of Earth Scientist Series by Springer-Verlag, 1st Edition

Verma, S.P., 1999. Geochemistry of evolved magmas and their relationship to subduction-unrelated mafic volcanism at the volcanic front of the central Mexican Volcanic Belt. Journal of Volcanology and Geothermal Research, 93: 151-171.

Verma, S.P., 2000. Geochemical evidence for a lithospheric source for magmas from Los Humeros caldera, Puebla, Mexico. Chemical Geology, 164: 35-60.

Verma, S.P., 2001a. Geochemical evidence for a Rift-Related Origin of bimodal volcanism at Meseta Río San Juan, North-Central
Mexican Volcanic Belt. International Geology, Review, 43: 475-493.

Verma, S.P., 2001b. Geochemical evidence for a lithospheric source for magmas from Acoculco Caldera, Eastern Mexican Volcanic Belt. International Geology Review, 43: 31-51.

Verma, S.P., 2005. Estadística Básica para el Manejo de Datos Experimentales: Aplicación a la Geoquímica (Geoquimiometría) (in Spanish). Universidad Nacional Autónoma de México, México, D.F.

Verma, S.P., 2015. Origin, evolution, and tectonic setting of the eastern part of the Mexican Volcanic Belt and comparison with the Central American Volcanic Arc from conventional multielement normalized and new multidimensional discrimination diagrams and discordancy and significance tests. Turkish Journal of Earth Sciences, 24: 111-164.

Verma, S.P., Armstrong-Altrin, J.S., 2013. New multi-dimensional diagrams for tectonic discrimination of siliciclastic sediments and their application to Precambrian basins. Chemical Geology, 355: $117-180$

Verma, S.P., Armstrong-Altrin, J.S., 2016. Geochemical discrimination of siliciclastic sediments from active and passive margin settings. Sedimentary Geology, 332: 1-12.

Verma, S.P., Díaz-González, L., Armstrong-Altrin, J.S., 2016. Application of a new computer program for tectonic discrimination of Cambrian to Holocene clastic sediments. Earth Science Informatics, 9: 151-165

Wang, Z., Wang, J., Fu, X., Zhan, W., Yu, F., Feng, X., Song, C., Chen, W., Zeng, S., 2017. Organic material accumulation of Carnian mudstones in the North Qiangtang Depression, eastern Tethys: controlled by the paleoclimate, paleoenvironment, and provenance. Marine and Petroleum Geology, 88: 44-457.

Wang, Z., Wang, J., Fu, X., Zhan, W., Armstrong-Altrin, J.S., Yu, F., Feng, X., Song, C., Zeng, S., 2018. Geochemistry of the Upper Triassic black mudstones in the Qiangtang Basin, Tibet: implications for paleoenvironment, provenance, and tectonic setting. Journal of Asian Earth Sciences, 160: 118-135.

WedepohI, H.K., 1995. The composition of the continental crust. Geochimica et Cosmochimica Acta, 59: 1217-1232.

Xie, Y., Chi, Y., 2016. Geochemical investigation of dry- and wet-deposited dust during the same dust-storm event in Harbin, China: constraint on provenance and implications for formation of aeolian loess. Journal of Asian Earth Sciences, 120: 43-61.

Yang, J-H., Du, Y-S., 2017. Weathering geochemistry and palaeoclimate implication of the Early Permian mudstones from eastern Henan Province, North China. Journal of Palaeogeography, 6: 370-380.

Yañez-Arancibia, A., Day, J.W. Jr., 1982. Ecological characterization of Terminos Lagoon: a tropical lagoon estuarine system in the southern Gulf of Mexico. Oceanologica Acta, 5: 431-500.

Zaid, S.M., 2013. Provenance, diagenesis, tectonic setting and reservoir quality of the sandstones of the Kareem Formation, Gulf of Suez, Egypt. Journal of African Earth Sciences, 85: 31-52.

Zaid, S.M., 2017. Provenance of coastal dune sands along Red Sea, Egypt. Journal of Earth System Science, 126: 50.

Zaid, S.M., Gahtani, F.A., 2015. Provenance, diagenesis, tectonic setting and geochemistry of Hawkesbury sandstone (Middle Triassic), southern Sydney Basin, Australia. Turkish Journal of Earth Sciences, 24: 72-98.

Zhang, S., Hu, Z., Wang, H., 2018. A retrospective review of microbiological methods applied in studies following the deep-water horizon oil spill. Frontiers in Microbiology, 9: 520. 